Aus der Klinik für Neurochirurgie

(Prof. Dr. med. V. Rohde)

der Medizinischen Fakultät der Universität Göttingen

\title{
A combination of repurposed drugs reduces the proliferation and viability of glioblastoma cells
}

\author{
INAUGURAL-DISSERTATION \\ zur Erlangung des Doktorgrades \\ der Medizinischen Fakultät der \\ Georg-August-Universität zu Göttingen
}

vorgelegt von

Aleksandra Sachkova

aus

Moskau, Russland 
Dekan:

Betreuungsausschuss

Betreuer:

Prüfungskommission

Referent:

Ko-Referent:

Datum der mündlichen Prüfung: 12.10.2021
Prof. Dr. med. W. Brück

Prof. Dr. med. V. Rohde

Prof. Dr. med. V. Rohde

Univ.-Prof. Dr. med. Ch. Kramm 
Hiermit erkläre ich, die Dissertation mit dem Titel "A combination of repurposed drugs reduces the proliferation and viability of glioblastoma cells" eigenständig angefertigt und keine anderen als die von mir angegebenen Quellen und Hilfsmittel verwendet zu haben.

Göttingen, den 30.09.2021 
The data on which the present study is based has been partially published:

Sachkova A, Sperling S, Mielke D, Schatlo B, Rohde V, Ninkovic M (2019):

Combined applications of repurposed drugs and their detrimental effects on glioblastoma cells. Anticancer Res $\underline{39}$, 207-214 


\section{Table of contents}

List of Figures .......................................................................................III

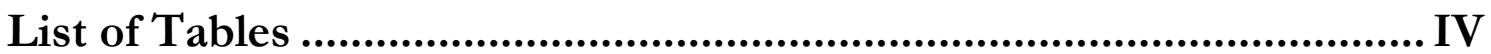

List of Abbreviations............................................................................... V

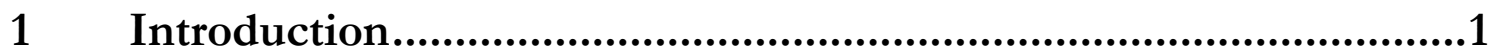

1.1 Glioblastoma multiforme (GBM): definition and epidemiology ................................. 1

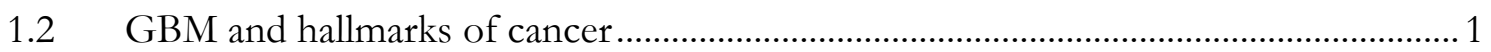

1.3 Genetic and molecular characteristics of GBM ....................................................... 2

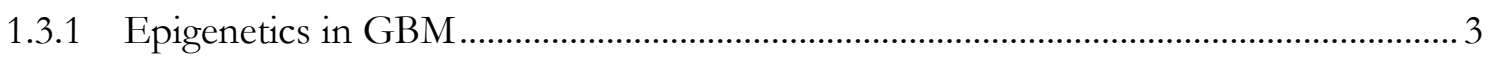

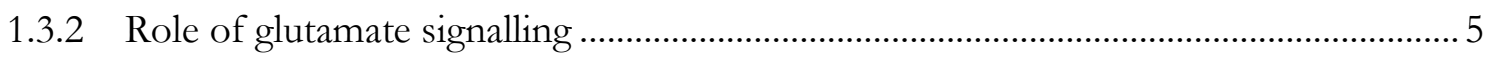

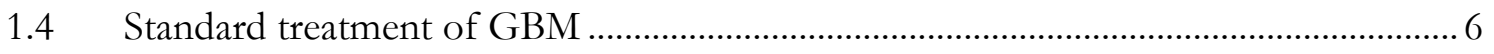

1.4.1 Treatment possibilities for a newly diagnosed GBM ..................................................... 6

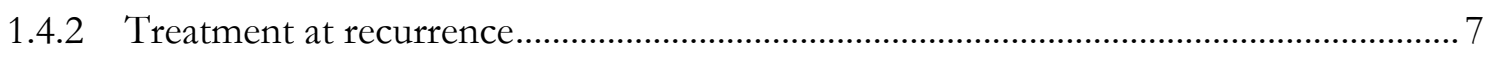

1.5 Drug combinations and drug repurposing in GBM treatment ..................................... 8

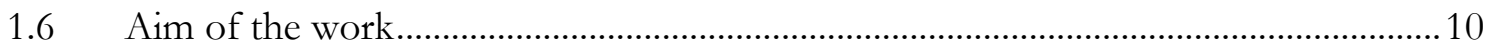

2 Materials and Methods ........................................................ 11

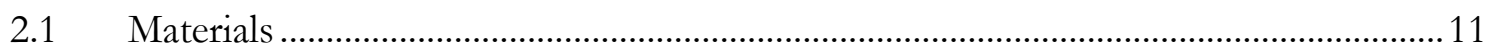

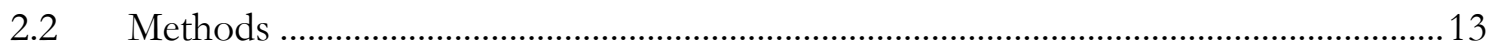

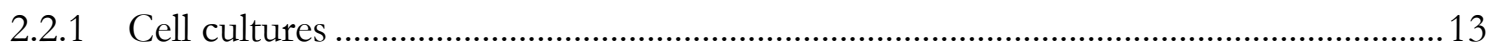

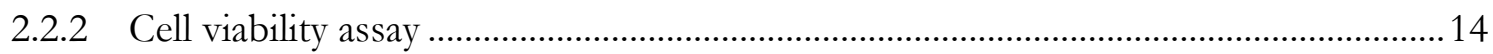

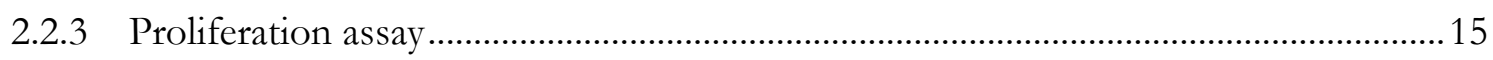

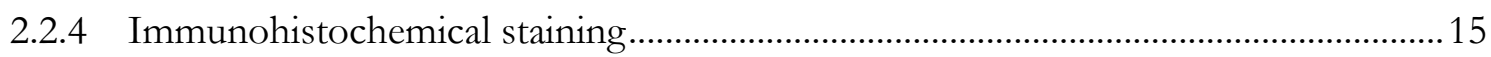

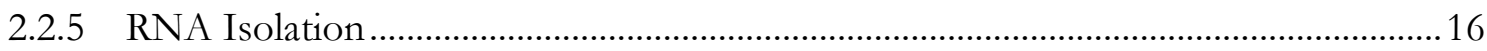

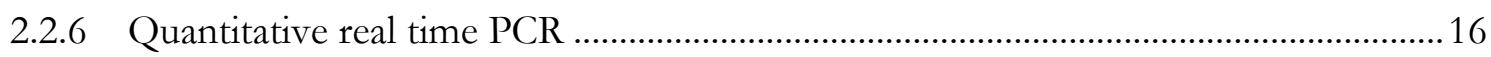

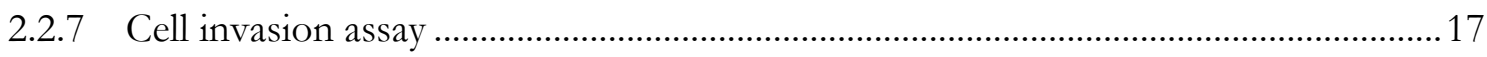

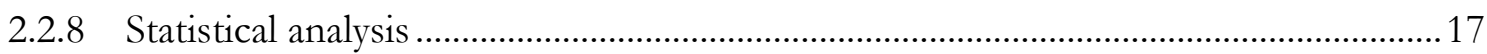

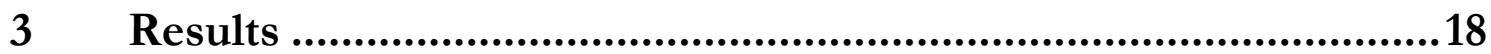

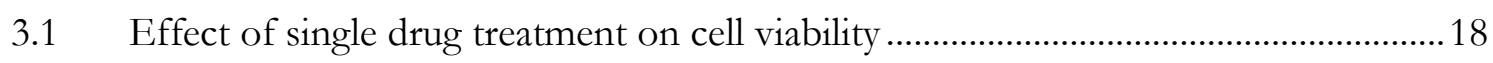

3.2 Effect of the combination treatment on cell viability ................................................. 19

3.3 Effect of the combination treatment with temozolomide (TMZ) on cell

3.4 Effect of combination treatment with radiation on cell viability.................................2 
3.5 Inhibition of GBM cell proliferation by combined drug treatment............................24

3.6 Effect of single or combination treatment on TFPI2 gene expression and cell

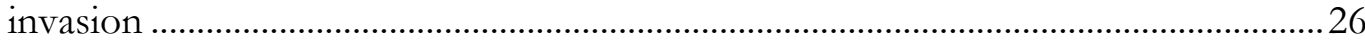

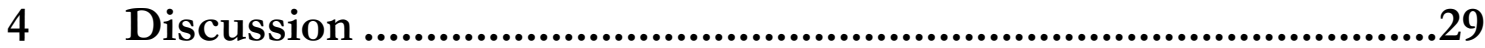

4.1 Effect of single VPA, TCA and riluzole treatments ....................................................29

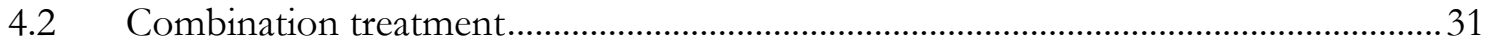

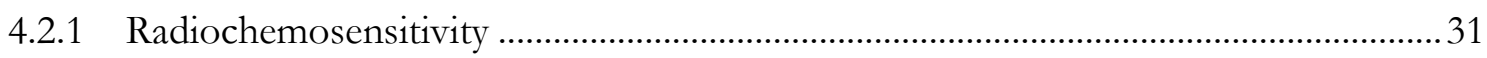

4.2.2 Benefits of combined treatment on TFPI2 expression and invasion............................32

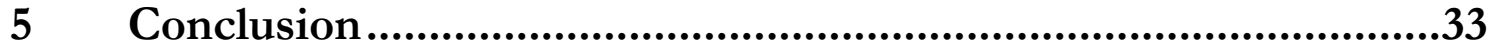

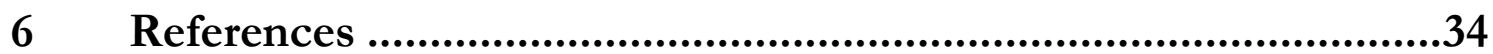




\section{List of Figures}

Figure 1. Schematic representation of the survival assay

Figure 2. Schematic representation of the in vitro chemoradiation assay.

Figure 3. MTT assays for U87MG cell viability after single treatments with (A) valproic acid (VPA), (B) tranylcypromine hydrochloride (TCA), and (C) riluzole hydrochloride (Ril)

Figure 4. MTT assays for U87MG cell viability after combination treatment with (A) riluzole (Ril) + valproic acid (VPA), (B) riluzole + tranylcypromine hydrochloride (TCA), and (C) TCA + VPA.

Figure 5. MT'T assays for U87MG viability after combination treatment between (A) valproic acid (VPA), (B) tranylcypromine hydrochloride (TCA), (C) riluzole hydrochloride (Ril) with temozolomide (TMZ)

Figure 6. MTT assays for U87MG viability after combining radiation and (A) valproic acid (VPA), (B) tranylcypromine hydrochloride (TCA), (C) riluzole hydrochloride (Ril)

Figure 7. Beneficial effects of combined treatment on proliferation of U87MG cells.

Figure 8. Expression of tissue factor pathway inbibitor 2 (TFPI2) in U87MG cells treated with valproic acid (VPA), tranylcypromine hydrochloride (TCA) and riluzole hydrochloride (Ril)

Figure 9. Effects of combined treatment on the invasiveness of U87MG cells 


\section{List of Tables}

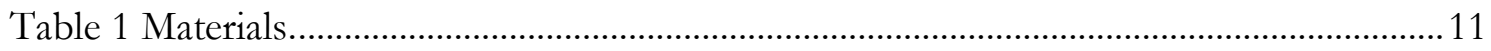

Table 2. Student`s t-test for single treatment compared to combination treatment.............21 


\section{List of Abbreviations}

$\mathrm{ACNU}$

AML

non-APL AML

APL

ATRA

$\mathrm{BCNU}$

$\mathrm{CCNU}$

CIM

CNS

CpG island

DAPI

$\mathrm{ddH}_{2} \mathrm{O}$

DIPG

DKFZ

DMSO

DNA

DSB

EDTA

EORTC

FCS

FDA

GBM

G-CIMP

GCS

GRM1

HDACi

$\mathrm{Ki}$

MEM

MTT

NAD

NCIC

NEAA

OS

PBS

PFS

QoL

RNA

RT-PCR 3-[(4-amino-2-methylpyrimidin-5-yl)methyl]-1-(2-chloroethyl)-1nitrosourea (nimustine)

Acute myeloid leukaemia

Non-acute promyelocytic leukaemia acute myeloid leukemia

Acute promyelocytic leukaemia

All-trans-retinoid-acid

1,3-bis(2-chloroethyl)-1-nitrosourea (carmustine)

1-(2-chloroethyl)-3-cyclohexyl-1-nitrosourea (lomustine)

Cell invasion/migration

Central nervous system

Cytosine/Guanine island

4',6-Diamidino-2-phenylindole

Double distilled water

Diffuse Intrinsic Pontine Glioma

Deutsches Krebsforschungszentrum

Dimethylsulfoxide

Deoxyribonucleic acid

DNA double-strand breaks

Ethylenediaminetetraacetic acid

European Organisation for Research and Treatment of Cancer Fetal calf serum

Food and Drug Agency

Glioblastoma multiforme

CpG island methylator phenotype

Glioma stem cells

Metabotropic glutamate receptor 1

Histone deacetylase inhibitors

Inhibition constant value

Minimum Essential Medium

3-(4,5-Dimethylthiazol-2-yl)-2,5-diphenyl tetrazolium-bromide

Nicotinamide adenine dinucleotide

National Cancer Institute of Canada

Non-essential amino acids

Overall survival

Phosphate buffered saline

Progression-free survival

Health-related quality of life

Ribonucleic acid

Reverse transcription polymerase chain reaction 


$\begin{array}{ll}\text { ROS } & \text { Reactive oxygen species } \\ \text { Rpm } & \text { Revolutions per minute } \\ \text { SAHA } & \text { Suberoylanilide hydroxamic acid (Vorinostat) } \\ \text { SEM } & \text { Standard error of the mean } \\ \text { TCA } & \text { Tranylcypromine } \\ \text { TCGA } & \text { The Tumor Genome Atlas } \\ \text { TMZ } & \text { Temozolomide } \\ \text { VPA } & \text { Valproic acid } \\ \text { WHO } & \text { World Health Organisation } \\ \text { Wt } & \text { Wildtype }\end{array}$

\section{Gene/Protein names}

\begin{tabular}{|c|c|}
\hline AR & Androgen receptor \\
\hline AMPA & $\alpha$-Amino-3-hydroxy-5-methyl-4-isoxazolepropionic acid \\
\hline ATRX & $\begin{array}{l}\text { Alpha-Thalassemia/mental retardation syndrome, non-deletion type, } \\
\text { X-linked }\end{array}$ \\
\hline 2-HG & 2-Hydroxyglutarate \\
\hline $\mathrm{AKT}$ & RAC-alpha serine/threonine-protein kinase \\
\hline BRAF & B-Raf proto-oncogene \\
\hline $\mathrm{CDKN} 2 \mathrm{~A} / \mathrm{CDKN} 2 \mathrm{~B}$ & $\begin{array}{l}\text { Cyclin-dependent kinase inhibitor 2A/c Cyclin-dependent kinase } \\
\text { inhibitor } 2 \mathrm{~B}\end{array}$ \\
\hline $\mathrm{C} / \mathrm{EBP} 2$ & CAATT/enhancer binding protein \\
\hline c-myc & Cancer Myelocytomatosis transcription factor \\
\hline Cnx43 & Connexin 43 \\
\hline CoRest & $\begin{array}{l}\text { Corepressor of RE1 silencing transcription factor/neural-restrictive } \\
\text { silencing factor }\end{array}$ \\
\hline $\mathrm{CtBP}$ & C-terminal-binding protein 1 \\
\hline DAXX & Death Domain Associated Protein \\
\hline DNMT & DNA methyltransferase \\
\hline DNMT1 & DNA (cytosine-5)-methyltransferase 1 \\
\hline EAAT & Excitatory amino acid transporter \\
\hline EGFR & Epidermal growth factor receptor \\
\hline ELL & RNA polymerase II elongation factor \\
\hline ER & Estrogen receptor \\
\hline GABA & Gamma-aminobutyric acid \\
\hline GLUT3 & Glucose transporter 3 \\
\hline GSK3 & Glycogen Synthase-Kinase 3 \\
\hline H3.3 & Histone 3.3 \\
\hline HDAC & Histone deacetylase \\
\hline HIF & Hypoxia-induced factor \\
\hline HMBS & Hydroxymethylbilane synthase \\
\hline HPRT1 & Hypoxanthine Phosphoribosyltransferase 1 \\
\hline $\mathrm{IDH} 1 / 2$ & Isocitrate Dehydrogenase $1 / 2$ \\
\hline iGluR & Ionotropic glutamate receptor \\
\hline
\end{tabular}


$\mathrm{JmjC}$

$\mathrm{LSD} 1 / 2$

$\mathrm{MAO}$

MAPK

mGluR

MGMT

MLL

mTOR

MYPT1

NuRD

p21

p27

PD-L1

PI3K

PTEN

RARa

RB pathway

RTK pathway

SIRT

TERT

TF

TFPI2

TGFbR1

TP53

Wnt
Jumonji C

Lysine-specific demethylase $1 / 2$

Monoamine oxidase

Mitogen-activated protein kinase

Metabotropic glutamate receptor

O-6-Methylguanine-DNA Methyltransferase

Myeloid/lymphoid leukemia or mixed lineage leukemia gene

Mammalian Target of Rapamycin

Myosin phosphatase target subunit 1

Nucleosome Remodeling and Deacetylase Complex

Protein 21

Protein 27

Programmed death-ligand 1

Phosphoinositol-3 Kinase

Phosphatase and tensin homolog

Retinoic acid receptor alpha

Retinoblastoma pathway

Receptor tyrosine kinase pathway Sirtuin

Telomerase reverse transcriptase

Tissue factor

Tissue factor pathway inhibitor 2

Tissue growth factor $\mathrm{b}$ receptor 1

Tumour protein 53

Wingless-related integration site 


\section{Introduction}

\subsection{Glioblastoma multiforme (GBM): definition and epidemiology}

Brain tumours make up $2 \%$ of all cancers in adults (Stewart et al. 2014). The most aggressive form of the glial brain tumour - glioblastoma multiforme (GBM) - accounts for about $15 \%$ all intracranial neoplasms and 45-50\% of all malignant brain tumours. The annual incidence is about three to four cases per 100,000 in the Caucasian population (Louis et al. 2016). Despite improvements in surgical and medical treatments, glioblastoma remains a tumour with a very poor prognosis - the mean overall survival (OS) is 14.6 months and the two-year survival rate is $30 \%$ (http://www.abta.org/brain-tumor-information/types-oftumors/glioblastoma.html; accessed on 29.08.2016).

\subsection{GBM and hallmarks of cancer}

Glioblastoma multiforme is characterised by having 'hallmarks of cancer', a term introduced by Hanahan and Weinberg in 2011 (resisting cell death, sustaining proliferative signalling, evading growth suppressors, enabling replicative immortality, inducing angiogenesis and activating invasion and metastasis).

GBM is characterised by high resistance to cell death. There are three different types of cell death: apoptosis, autophagy and necrosis. Apoptosis is a highly regulated 'programmed' cell death. Autophagy is activated as a response to environmental stress and nutrient depletion. As a result, a tumour can use the produced energy, which further promotes its growth and invasion. Cell death by necrosis results in autolysis, which promotes inflammation, activation of the immune system and therefore protumour environment and cancer progression. GBM, to a large extent, is resistant to cell death by apoptosis due to impairment of the Tumourprotein 53 (TP53) or Retinoblastoma (RB) genes, but it is more prone to death by necrosis or autophagy (Lefranc and Kiss 2006; Jiang et al. 2009, Degenhardt et al. 2006, Nørøxe et al. 2017). Drugs like temozolomide (TMZ), a chemotherapeutic used for GBM, induce death by autophagy (Kanzawa et al. 2004).

Glioblastoma is also characterised by sustained proliferative signalling. Normal cell growth depends on signalling of a tightly regulated cell cycle, which allows regulation of proliferation and maintenance of tissue homeostasis. These processes are disrupted in cancers, and cancer cells develop mechanisms to sustain a proliferative signature by the aberration in their gene 
signatures. Glioblastoma cells can show activation of oncogenes PI3K, RAS and EGFR, or inactivation of tumour suppressor genes like TP53, RB, Phosphatase and tensin homolog (PTEN) and Mammalian target of Rapamycin (mTOR).

Another cancer hallmark seen in GBM is cell invasiveness. The tumour spreads by local invasion; distant metastases are not typical for GBM (Johansen et al. 2016). One of the reasons for the loss of adherence between GBM cells is the downregulation of $\mathrm{Cx} 43$. This promotes the production of extracellular matrix-degrading enzymes by protumoural immune cells, which again reduces the adherence of GBM cells (Sin et al. 2012).

The epithelial-mesenchymal transition (EMT), characterised by the transformation of epithelial cells into motile mesenchymal cells, is another feature responsible for GBM progression (reviewed in Iser et al. 2017). The epithelial-mesenchymal transition implies changes in gene expression as well as non-transcriptional alterations. One of the genes involved in the EMT is tissue factor pathway inbibitor 2 (TFPI2). The gene product TFPI2 is a protease which inhibits circulating factor $\mathrm{Xa}$ and the tissue factor (TF) induced tenase complex. This protein can also inhibit other proteins involved in haemostasis and neoangiogenesis, such as TF/VIIa complex, factor XIa, plasmin, matrix metalloproteases (MMPs), trypsin, chymotrypsin and plasma kallikrein (Wojtukiewicz et al. 2003).

Tissue factor protease inhibitor 2 is expressed in various normal tissue types. The protein is mainly produced by endothelial cells of small blood vessels. It is involved in extracellular matrix remodelling, cellular invasion and angiogenesis during cancer progression (Wojtukiewicz et al. 2003; Gessler et al. 2011). Tissue factor protease inhibitor 2 potentially serves as a negative regulator of cancer development. Tissue factor protease inhibitor 2 expression decreases from higher to lower stages of different cancers (Zhang et al. 2012). Multiple studies have suggested that TFPI2 is downregulated during glioma progression, whereas TFPI2 overexpression can induce apoptosis in glioma cells (Tasiou et al. 2001; George et al. 2007).

\subsection{Genetic and molecular characteristics of GBM}

Whole-genome sequencing studies of the last decade have allowed a precise characterisation of GBM molecular heterogeneity (Brennan et al. 2013). The pathomorphological classification of brain tumours is defined by the WHO Classification of tumours of the central nervous system (CNS) (Louis et al. 2016). Glioblastoma is characterised by aggressive infiltrating growth, nuclear atypia, cellular pleomorphism, high rates of mitotic activity, 
vascular thrombosis, microvascular proliferation and necrosis. Two major molecular tumour types are distinguished according to the somatic mutation in the isocitrate dehydrogenase (IDH1) gene: IDH1/2 wildtype glioblastoma and IDH1/2 mutant glioblastoma (Louis et al. 2016). Mutant IDH1/2 is an oncogene that catalyses the reduction of $\alpha$-ketoglutarate to 2-hydroxyglutarate (2-HG). The accumulation of 2-HG then interacts with hypoxia-induced pathways and leads to an increase in the levels of reactive oxygen species (ROS) and a prooncogenic effect in cells (reviewed in Kloosterhof et al. 2011).

The tumour entities also differ in their epidemiology, prognosis and molecular features. Glioblastoma with wild-type IDH1/2 gene is seen in $90 \%$ of patients and IDH1/2 mutant GBM in only ca. $10 \%$ of cases. IDH1/2 wild-type GBM corresponds to a primary (de novo) tumour with a short clinical history (Louis et al. 2016). Glioblastoma with the IDH1/2 gene mutation is considered to be a secondary tumour which arises from a lower grade precursor lesion (Lai et al. 2011). Patients with IDH1/2 mutant GBM have a better prognosis, with overall survival (OS) of 31 months (Louis et al. 2016).

The most frequently altered tumour-driving pathways in GBM are $R B, T P 53$, and receptor tyrosine kinase (RTK) signalling (Brennan et al. 2013). The Tumour Genome Atlas (TCGA) project has recently defined molecular subtypes of GBM as classical, neural, proneural and mesenchymal, each with specific gene expression signatures (Verhaak et al. 2010). Gene expression patterns in different molecular subtypes of glioblastoma correlate with the markers of various cell types (oligodendrocytes, astrocytes and neurons) in the CNS and could possibly define their genetic origin. However, various studies show the coexistence of diverse cell populations with individual expressional profiles and oncogenic driver pathways in the same tumour, as well as molecular shifts in primary and recurrent cancer. This tumour heterogeneity contributes to the high level of therapy resistance (Meyer et al. 2015).

\subsubsection{Epigenetics in GBM}

Epigenetic modifications are alterations to the deoxyribonucleic acid (DNA) and chromatin structure which control transcriptional accessibility and widely regulate gene expression. Epigenetics plays an important role in GBM pathogenesis (reviewed in Clarke et al. 2013), as GBM tumours show aberrant patterns of gene promoter methylation and chromatin state (Martinez and Esteller 2010). Epigenetic mechanisms are also important for the reprogramming of the tumour-initiating stem cells (Suvà et al. 2014a), and therapy resistance is regulated at the epigenetic level. The best-known resistance mechanism is attributed to the activity of O-6-methylguanine-DNA methyltransferase (MGMT) in tumour cells. This gene 
codes for a suicide repair protein that removes alkyl groups from the O6 position of guanine following their induction by the chemotherapy with alkylating agents. Patients with a methylated MGMT promoter, when treated with standard radiochemotherapy with temozolomide (TMZ), show better survival when compared with patients with an unmethylated promoter (Stupp et al. 2009). Chemotherapy-sensitive and chemotherapyresistant cells show different patterns of histone modifications (Costello et al. 1994).

Glioblastoma shows aberrations at the level of histone-modifying enzymes. These proteins control gene expression by regulating the condensation of chromatin and the access of nuclear proteins to their target genes. Different mechanisms exist for histone modifications, including acetylation, methylation, phosphorylation and ubiquitination (reviewed in Maleszewska and Kaminska 2013). Histone acetylation is important for the relaxation of chromatin, which occurs by the addition of negatively charged lysine residues that disrupt the electrostatic affinity between histones and DNA, leading to chromatin re-condensation and increased gene expression. This process is modified by histone acetyltransferases and histone deacetylases. The histone deacetylase (HDAC) protein family consists of 18 enzymes assigned to four classes: (zinc ( $\mathrm{Zn}$ )- and iron (Fe)-dependent class I (HDAC 1, 2, 3, 8), IIa (HDAC 4, 5, 7, 9), IIb (HDAC 6, 10) and IV (HDAC11), and the nicotinamide adenine dinucleotide (NAD)-dependent class III (sirtuin 1-8 (SIRT 1-8)) (reviewed in Khan and La Thangue 2012).

Enzymes of the HDAC family play a complex role in cancer initiation and progression. The inhibition of HDAC has a wide range of effects on cellular and tissue processes, including the cell cycle, apoptosis, autophagy, cell differentiation, angiogenesis and immune responses (reviewed in Eckschlager et al. 2017). The members of the HDAC family show aberrant expression patterns in GBM and affect patient prognosis (Lucio-Eterovic et al. 2008; Yang et al. 2015). Histone deacetylases seem to play a role in the development of therapy resistance (Zhang Z et al. 2016), whereas treatment with HDAC inhibitors can promote sensitivity to chemotherapy with alkylating drugs (reviewed in Eckschlager et al. 2017).

Another important group of enzymes in cancer development are histone demethylases. Histone methylation takes place on lysine residues, which can be mono-, di- and trimethylated. The reaction is performed by lysine methyltransferases and lysine demethylases. It can be distinguished between flavin adenine dinucleotide (FAD)-dependent amine oxidase type demethylases and Jumonji C (JmjC)-domain demethylases (reviewed in Rotili and Mai 2011). 
Lysine-specific demethylase 1 (LSD1) is a FAD-dependent amine oxidase. It is the first explored histone demethylase, and it plays a significant role in various cancers (reviewed in Zheng et al. 2015). This protein is overexpressed in GBM tissue and its expression increases during GBM tumour progression (Yi et al. 2016). This enzyme specifically demethylates mono- and di-methylated lysines. Its function is highly dependent on its interaction partners, which are involved in a great number of processes such as cell growth, differentiation, survival, energy metabolism, EMT and apoptosis. Lysine-specific demethylase 1 is a member of chromatin remodelling and transcription complexes, such as the corepressor of RE1 silencing transcription factor/neural-restrictive silencing factor (CoRest) (Lee et al. 2005) or the nucleosome remodelling and deacetylase complex (NuRD) (Wang et al. 2009), and it is recruited by transcription factors and nuclear receptors, such as the retinoic acid receptor (RAR) (Schenk et al. 2012a), androgen receptor (AR) (Metzger et al. 2005a) or cancer myelocytomatosis transcription factor (c-myc) (Amente et al. 2010). The majority of transcriptional complexes are largely considered repressive, but the cooperation of LSD1 with AR activates gene transcription (Metzger et al. 2005b). Moreover, the non-histone protein p53 is a substrate for LSD1 (reviewed in Zheng et al. 2015).

Lysine-specific demethylase 1 is important for differentiation processes and the maintenance of pluripotency. This enzyme demethylates histones at the promoters of stemness genes and controls their expression (Adamo et al. 2011). Lysine-specific demethylase 1 regulates neuronal cell development and represses the expression of neuronal genes (Ballas et al. 2005). This same enzyme is also involved in the EMT (Phillips et al. 2014). Lysine-specific demethylase 1 participates in the wingless-related integration site (Wnt) pathway and regulates metastasis-associated gene expression (Wang et al. 2009; Song et al. 2015).

\subsubsection{Role of glutamate signalling}

Dysregulated glutamate signalling is an important feature of different malignancies, including GBM (reviewed in Willard and Koochekpour 2013). Different tumours show aberrant expressions of ionotropic and metabotropic glutamate receptors (iGluR and mGluR) as well as somatic mutations in these genes, which had tumour-driving capacity in in vivo studies (reviewed in de Groot and Sontheimer 2011). Abnormal intratumoral glutamate release has a pro-epileptogenic effect and produces toxic effects on surrounding brain tissue, thereby supporting the invasion of tumour cells. This imbalance could be explained by impaired glutamate uptake (Ye and Sontheimer 1999) due to the overexpression of the metabotropic glutamate receptor (mGluR) (reviewed in Brocke et al. 2010), by a decreased expression, 
delocalisation or dysfunction of glutamate transporters (excitatory amino acid transporters, EAAT) and by increased levels of the glutamate/cysteine exchange transporter $\mathrm{x}_{\mathrm{c}}{ }^{-}$(reviewed in de Groot and Sontheimer 2011).

Excessive glutamate signalling is associated with chemotherapy resistance and promotes tumour cell survival and proliferation. Possible mechanisms are the overactivation of PI3K/PTEN/RAC-alpha serine/threonine-protein kinase (AKT) and mitogen-activated protein (MAPK) signalling pathways, as well PTEN-mediated disinhibition of the oncogene

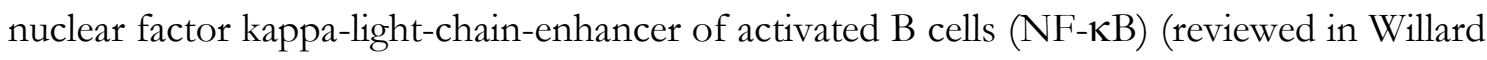
and Koochekpour 2013). Glutamate-induced activation of $\alpha$-amino-3-hydroxy-5-methyl-4isoxazole propionic acid (AMPA) receptors promotes detachment from the extracellular matrix and invasion (de Groot and Sontheimer 2011). The multiple effects of glutamate on glioma progression make it a prospective target for anticancer therapy.

\subsection{Standard treatment of GBM}

\subsubsection{Treatment possibilities for a newly diagnosed GBM}

An important part of the treatment of newly diagnosed GBM is surgical resection. In case of an unresectable tumour, a diagnostic biopsy is carried out. The operation is routinely followed by adjuvant-combined radiochemotherapy for 6 weeks and a subsequent six cycles (5/28 days regime) of maintenance chemotherapy with TMZ. This treatment scheme is based on a large multicentre randomised trial (NCT00006353) conducted by the European Organisation for Research and Treatment of Cancer (EORTC) and the National Cancer Institute of Canada (NCIC). The combination treatment increases the overall survival for 2.5 months and progression-free survival (PFS) for 1.9 months compared to adjuvant radiotherapy alone (Stupp et al. 2009).

The recent Ce'TeG/NOA-09 Phase III trial compared a lomustine/TMZ combination therapy vs. the standard treatment in 141 patients (newly diagnosed GBM with MGMT promoter methylation). This trial showed an improved OS in the intervention arm (48.1 vs. 31.4 months) and acceptable toxicity of the treatment, indicating that the combination treatment might be better in patients with MGMT promoter methylation. However, the small trial size could be a limiting factor for the interpretation of its results (Herrlinger et al. 2019).

The implantation of carmustine (BCNU)-loaded polymers (Gliadel wafers) is an additional local treatment possibility for GBM, with a survival advantage (13.9 months vs. 11.6 months) confirmed in Phase III controlled randomised trial (Hart et al. 2011). 
Another FDA-approved treatment for newly diagnosed GBM is tumour-treating fields (T'TF), which target mitoses of tumour cells by low-intensity intermediate-frequency alternating electric fields. A randomised controlled EF-14 trial showed an increase in progression-free survival of three months ( 7.1 months vs. 4 months) and overall survival of 4.9 months (20.5 months vs. 15.6 months) compared to standard radiochemotherapy (Stupp et al. 2015).

\subsubsection{Treatment at recurrence}

In cases of recurrence, no standard therapy is defined. Reoperation and radiotherapy remain therapeutic possibilities (reviewed in Seystahl et al. 2016). One of the treatment modalities is TMZ re-challenge. Temozolomide was approved for the treatment of recurrent GBM after a phase II trial, where the standard 5/28 150-200 mg/m² schedule was superior to procarbazine with a six-month PFS of $21 \%$ vs $8 \%$ (Yung et al. 2000). Different TMZ regimens were studied, with the most common being low-dose metronomic TMZ (40-50 mg/m² daily), 1-week-on/1-week-off (75-100 mg/m²) and 3-weeks-on/1-week-off $\left(150 \mathrm{mg} / \mathrm{m}^{2}\right)$ (reviewed in Seystahl et al. 2016).

Nitrosoureas, such as carmustine (BCNU), lomustine (CCNU), nimustine (ACNU) and fotemustine, are classical DNA-alkylating drugs often used as treatment alternatives for recurrent GBM. Phase II and III trials showed a maximum PFS of six months and OS of 11 months for monotherapy with nitrosourea agents. The effect seems to depend on the MGMT methylation status, but a combination of high-dose therapy is limited due to the high rate of hematologic toxicity (reviewed in Seystahl et al. 2016).

Bevacizumab was tested either as monotherapy (PFS 3.3-4.6 months, OS 7.75-10 months) or in combination with other substances (PFS 2-6.4 months, OS 3.75-11.2 months) (reviewed in Diaz et al. 2017). However, due to disappointing results of the RTOG 0825 and AVAglio studies, which failed to show a significant effect on the OS, bevacizumab is no longer recommended for the treatment of recurrent GBM (Khasraw et al. 2014). The recent GLARIUS trial, a randomised study for combination treatment with bevacizumab and irinotecan, showed improved PFS but no difference in OS when compared to TMZ treatment (Herrlinger et al. 2016).

Various Phase I/II trials have approached the use of target molecular therapies, for example, targeting EFGRvIII, PI3K/AKT/mammalian target of rapamycin (mTOR) pathway, the BRaf proto-oncogene (BRAF), the MET proto-oncogene or integrins, but these trials either 
showed no benefit for the survival of patients with relapsed tumours or the evidence was limited to case reports. MET inhibitors showed a moderate effect in selected patients. Several agents, such as the proteasome inhibitor marizomib, are currently undergoing clinical trials (Mooney et al. 2019; reviewed in Rhun et al. 2019). An emerging treatment modality is an immune therapy. However, randomised studies for programmed death-ligand 1 (PD-L1) inhibitors, which were successful in various tumour types, such as lung cancer or melanoma, showed only limited effects in GBM (Lynes et al. 2018).

\subsection{Drug combinations and drug repurposing in GBM treatment}

The molecular complexity of the GBM tumour and its high level of therapy resistance creates a demand for the development of novel treatment approaches against this deadly disease. An evolving approach for facing challenges in cancer treatment, and therefore for GBM treatment as well, is drug repurposing. This strategy uses well-known mechanisms of older drugs for new therapeutic indications. Here, we concentrated on combining the drugs influencing epigenetic mechanisms and glutamate signalling to target different oncogenic pathways in GBM.

The treatment with histone deacetylase inhibitors (HDACi) shows a selective cytotoxic effect on malignant cells (Bolden et al. 2013). Histone deacetylase inhibitors are a superfamily of epigenetic enzymes divided into several classes based on their chemical structure and targeted HDAC. Therefore, pan-HDACi, which inhibits several HDACs from Classes I, II, IV, can be distinguished from selective HDACi, which specifically target different HDACs or HDAC classes (reviewed in Micelli and Rastelli 2015). Ongoing clinical trials are examining the use of HDAC inhibitors in cancer, and vorinostat (2006), romidepsin (2009) and belinostat (2014) were approved by FDA for the treatment of cutaneous T-cell lymphoma, and panobinostat (2015) was licensed by the FDA as therapy for multiple myeloma (reviewed in Suraweera et al. 2018; reviewed in Zhang et al. 2019). Histone deacetylase inhibitors have been effective in treating hematologic malignancies, but the success of monotherapies in solid tumours is still relatively modest due to various resistance mechanisms, including treatment-induced chromatin and epigenetic alterations. However, in combination treatment with radiotherapy, various chemotherapeutic agents (platinum-based chemotherapy, topoisomerase inhibitors) were found effective. Emerging trials are now evaluating combination treatments of $\mathrm{HDACi}$ and proteasome inhibitors, immune-modulating therapy and other epigenetic modifiers (reviewed in Suraweera et al. 2018). 
Valproic acid is a classic first-generation antiepileptic drug for the treatment of generalised and focal epilepsy, manic disorder, therapy-refractory depression or neuropathic pain (reviewed in Methaneethorn 2018). The drug has a wide, and not completely understood, spectrum of actions, including the regulation of gamma-aminobutyric acid (GABA) turnover and interaction with voltage-gated sodium channels (reviewed in Rogawski et al. 2016). Valproic acid is applied in the treatment of brain tumour-associated epileptic seizures (Perucca 2013, S. 201). Various studies show that VPA is an unspecific inhibitor of HDAC class I and IIa (Thotala et al. 2015). The antineoplastic effect of VPA used as an antiepileptic agent in patients with malignant gliomas has been widely discussed. Several prospective and retrospective clinical studies have shown a beneficial effect of the treatment with VPA on the OS of GBM patients (Weller et al. 2011).

Tranylcypromine is a classical antidepressant used as a second-line treatment option for therapy-refractive major depression or in cases of intolerance towards a first-line medication (www.fachinfo.de, accessed on 09.12.2019). The pharmacologic mechanism is irreversible inhibition of monoamine oxidases (MAO) and the upregulation of extra- and intracellular biogenic amines (serotonin, noradrenaline, dopamine) (https://www.drugbank.ca/drugs/DB00752, accessed on 09.12.2019). As part of the same amino oxidase family, LSD1 shares structural similarities with monoamine oxidases (MAO) A and B and can inhibit the histone demethylase LSD1 (reviewed in Hoffmann et al. 2012). Tranylcypromine was shown to have in vivo and in vitro effects on different cancers (Lee et al. 2013; Mould et al. 2015). Phase I/II clinical trials have evaluated the effect of tranylcypromine in combination with all-trans-retinoid-acid (ATRA) for the treatment of refractory non-acute promyelocytic leukaemia acute myeloid leukaemia (non-APL AML). Further LSD1 inhibitors are being studied in trials for various hematologic malignancies, small lung cell cancer and some neurologic diseases (reviewed in Fang et al. 2019).

One factor that contributes to the aggressive proliferative behaviour of GBM is abnormal glutamate release. Riluzole is routinely used for the treatment of amyotrophic lateral sclerosis (AML). This drug reduces the release of glutamate and glutamate-induced toxicity in brain tissue. The possible mechanisms imply the induction of glutamate transporter expression (Dall'Igna et al. 2013), as well as direct interaction with the metabotropic glutamate receptor 1 (GRM1) (reviewed in Yu et al. 2016). The treatment of cancer cells with riluzole results in growth arrest and increases in oxidative stress, DNA damage and apoptosis (reviewed in $\mathrm{Yu}$ et al. 2016). Recent studies have shown an effect of riluzole on several types of cancer, including breast cancer (Speyer et al. 2012), melanoma (Wen et al. 2014) and glioma (Zhang 
et al. 2015). A phase I trial of riluzole in unresectable Stage III and IV melanoma showed that $26 \%$ of patients had stable disease, but this, unfortunately, was not confirmed in a Phase II trial. Combination approaches with, for example, riluzole and tyrosine-kinase inhibitors, are currently being explored in clinical trials (reviewed in Willard and Koochekpour 2013).

\subsection{Aim of the work}

Glioblastoma multiforme shows high rates of recurrence despite maximal treatment with surgery and concomitant radiochemotherapy. Treatment that combines two or more therapeutic agents is a keystone of the therapy of many cancers. A strategy to simultaneously target core pathways together as well as epigenetic modifications could potentially help to overcome GBM tumour heterogeneity and prevent the development of therapy resistance. We checked the therapeutic potential of VPA, TCA and riluzole by analysing and comparing the effect of each as a single treatment versus their different combinations. The use of drug combinations targeting different pathways (histone regulation, DNA methylation, $\mathrm{PI} 3 \mathrm{~K} / \mathrm{AKT} / \mathrm{mTOR}$ pathway, glutamate signalling) could possibly boost the effect of the drugs and target different cell populations that exhibit different molecular properties. For example, VPA and TCA targeting HDAC class I/II and LSD1 could cooperate with protein complexes, transcription factors and nuclear receptors involved in stemness and differentiation (c-myc, NuRD, CoRest, RARa, b-catenin, etc.). Further interaction of riluzole with PI3K/AKT/mTOR pathway, which is known to be over-activated in stem cells, could then potentially lead to the induction of tumour cell differentiation and apoptosis.

In the present study, these drugs were also combined with standard temozolomide chemotherapy or radiation therapy and compared to the single standard treatment. All experiments were performed in vitro using an established U87MG GBM cell culture. We first tested cell viability with the MTT assay and the effect on proliferation with Ki67 immunohistochemistry. We also used reverse transcription polymerase chain reaction (RT-PCR) to test the effect of single drugs and drug combinations on the expression of a known tumour suppressor gene-TFPI2. Finally, the GBM cell invasiveness was tested using the xCELLigence system. 


\section{$2 \quad$ Materials and Methods}

\subsection{Materials}

Table 1 lists all chemicals and instruments used in the experiments performed in the laboratory of the neurosurgery clinics.

Table 1 Materials.

\begin{tabular}{|c|c|}
\hline Materials and chemicals & Sources \\
\hline Tranylcypromine hydrochloride & $\begin{array}{l}\text { Abcam Biochemicals/Cambridge, } \\
\text { United Kingdom }\end{array}$ \\
\hline $\begin{array}{l}\text { xCELLigence system } \\
\text { with 16-well plate CIM-Plate } 16\end{array}$ & $\begin{array}{l}\text { ACEA Biosciences Inc./San Diego, } \\
\text { USA }\end{array}$ \\
\hline $\begin{array}{l}\text { Matrigel }^{\mathrm{TM}} \text {, protein mixture resembling } \\
\text { extracellular matrix proteins in cell culture }\end{array}$ & BD Biosciences/San Jose, CA, USA \\
\hline $\begin{array}{l}\text { PCR thermocycler: The Professional Basic } \\
\text { Thermocycler }\end{array}$ & Biometra GmbH/Göttingen, Germany \\
\hline $\begin{array}{l}\text { CFX384 } \text { Touch }^{\text {TM }} \text { Real-Time PCR Detection } \\
\text { System }\end{array}$ & Bio-Rad/Munich, Germany \\
\hline Spectrophotometric absorption reader & Bio-TEK/Winooski, USA \\
\hline Syringes and $23 \mathrm{G}$, and $27 \mathrm{G}$ needles & Braun/Frankfurt am Main, Germany \\
\hline $\begin{array}{l}\text { Eppendorf BioPhotometer plus }{ }^{\mathrm{TM}} \\
\text { Eppendorf Centrifuge } 5424\end{array}$ & Eppendorf AG/Hamburg, Germany \\
\hline Hettich Rotixa/RP Centrifuge & Gemini BV/Apeldoorn, Netherlands \\
\hline Cell culture flasks, $75 \mathrm{~cm}^{2}$ & $\begin{array}{l}\text { Greiner GmbH/Pleidelsheim, } \\
\text { Germany }\end{array}$ \\
\hline $\mathrm{CO}_{2}$ Incubator, model C200 & $\begin{array}{l}\text { Labotect Labor-Technik-Göttingen } \\
\text { GmbH/Rosdorf Germany }\end{array}$ \\
\hline $\begin{array}{l}\text { Refrigerator Liebherr Profiline } \\
\text { Refrigerator Premium NoFrost } \\
\text { Refrigerator Öko Super }\end{array}$ & Liebherr/Bulle, Switzerland \\
\hline $\begin{array}{l}\text { Amicon Microcentrifuge } \\
\text { Acetone } \\
\text { Chloroform } \\
\mathrm{HCl} 37 \%\end{array}$ & Merck/Darmstadt, Germany \\
\hline Temozolomide & $\begin{array}{l}\text { MSD Sharp \& Dohme GMBH/Haar, } \\
\text { Germany }\end{array}$ \\
\hline NuAire -85 Ultra-low Temperature Freezer & NuAire/Plymouth, USA \\
\hline $\begin{array}{l}\text { Aqua Polymount, mounting medium for } \\
\text { mounting microscopic sections }\end{array}$ & $\begin{array}{l}\text { Polysciences Inc./Valley Road, } \\
\text { Warrington, PA, USA }\end{array}$ \\
\hline $\begin{array}{l}\text { miRNeasy mini kit (217004), kit for miRNA } \\
\text { isolation }\end{array}$ & QIAGEN/Venlo, Netherlands \\
\hline QIAzol Lysis Reagent & \\
\hline
\end{tabular}




\begin{tabular}{|c|c|}
\hline Materials and chemicals & Sources \\
\hline Isopropanol & Roth/Karlsruhe, Germany \\
\hline $\begin{array}{l}\text { Reagent and centrifuge tubes } \\
\text { Pipette tips } \\
\text { Cell culture scrapers } \\
\text { Eppendorf tubes }\end{array}$ & Sarstedt/Nümbrecht, Germany \\
\hline RS225A X-Ray Research System & Siemens/Munich, Germany \\
\hline $\begin{array}{l}\text { Valproic acid sodium salt } \\
\text { Triton X-100 (4-(1,1,3,3- } \\
\text { Tetramethylbutyl)phenyl-polyethylene glycol, } \\
\text { t-Octylphenoxypolyethoxyethanol, } \\
\text { Polyethylene glycol tert-octylphenyl ether) } 5 \\
\text { ml } \\
\text { Trypan blue (0.4\%) } \\
\text { Phosphate buffered saline (PBS) } \\
\text { 3-(4,5-dimethylthiazol-2-yl)-2.5-diphenyl } \\
\text { tetrazolium-bromide (MTT) } \\
\text { 4',6-diamidino-2-phenylindol (DAPI) }\end{array}$ & $\begin{array}{l}\text { Sigma-Aldrich/St. Louis, Missouri, } \\
\text { USA }\end{array}$ \\
\hline Systec Autoclave $3150 \mathrm{EL}$ & Systec GmbH/Linden, Germany \\
\hline Biosafety Cabinet SterilGARD III Advance & $\begin{array}{l}\text { The Baker company/Sanford, Maine, } \\
\text { USA }\end{array}$ \\
\hline $\begin{array}{l}\text { Biosafety Cabinet SteriGARD Class II, Type } \\
\text { A/B3 }\end{array}$ & \\
\hline $\begin{array}{l}\mathrm{CO}_{2} \text { Incubator Forms Series } \\
\text { Heraeus fresco } 21 \text { refrigerated centrifuge } \\
\text { MEM } 500 \mathrm{ml} \\
\text { FBS inactivated } \\
\text { Sodium pyruvate } \\
\text { NEAA } \\
\text { Sodium bicarbonate } \\
\text { Object slides (SuperFrost Plus) } \\
\text { Trypsin-EDTA }(0.04 \%)\end{array}$ & $\begin{array}{l}\text { ThermoFisher Scientific/Waltham, } \\
\text { Massachusetts, USA }\end{array}$ \\
\hline $\begin{array}{l}\text { Statistica (statistical analysis software } \\
\text { package) }\end{array}$ & TIBCO Software Inc. \\
\hline Riluzole hydrochloride & $\begin{array}{l}\text { Tocris bioscience/Bristol, United } \\
\text { Kingdom }\end{array}$ \\
\hline Normal horse serum & VECTOR Lab/Burlingame, CA, USA \\
\hline Primovert Inverted Routine Microscope & ZEISS/Oberkochen, Germany \\
\hline $\begin{array}{l}\text { Anti-Ki67 (mouse monoclonal, DAKO, } \\
\text { M7240, 1:50 in 1\% normal horse serum) }\end{array}$ & DAKO GmbH, Jena, Germany \\
\hline $\begin{array}{l}\text { Anti-mouse antibody from donkey labelled } \\
\text { with Alexa } 488 \text { Fluor (1:500 in 1\% normal } \\
\text { horse serum) }\end{array}$ & Life technologies/Carlsbad, USA \\
\hline
\end{tabular}




\begin{tabular}{|l|l|}
\hline Materials and chemicals & Sources \\
\hline TFPI2 primer & Primers (Sigma Aldrich/Darmstadt, \\
fw: GTCGATTCTGCTGCTTTTCC, & Germany) \\
rv: CAGCTCTGCGTGTACCTGTC & \\
HMBS primer & \\
fw: CGCATCTGGAGTTCAGGAGTA, & \\
rv: CCAGGATGATGGCACTGA & \\
HPRT1 primer & \\
fw: TGACCTTGAT'TATT'TTGCATACC, & \\
rv: CGAGCAAGACGTTCAGTCCT & \\
\hline
\end{tabular}

\subsection{Methods}

\subsubsection{Cell cultures}

Valproic acid, TCA and Riluzole were dissolved in double-distilled water. Temozolomide was dissolved in dimethylsulfoxide (DMSO).

GBM U87MG cells were used for the in vitro studies. The U87MG cell line was a kind gift from Julia Bode (Molecular Mechanisms of Tumour Invasion, Schaller research group, at the University of Heidelberg and DKFZ).

The cells were cultivated in minimal essential medium (MEM) in $75 \mathrm{~cm}^{2}$ flasks at $37^{\circ} \mathrm{C}$ in a humidified atmosphere of $5 \% \mathrm{CO}_{2}$. The cells were maintained until they reached the appropriate density (up to $75 \%$ confluence). Further culture or cell seeding for the experiments was conducted by removing the medium and washing the cells with $10 \mathrm{ml} 37^{\circ} \mathrm{C}$ warm phosphate-buffered saline (PBS). The cells were then incubated with $7 \mathrm{ml}$ trypsin (0.04\%) for 3-4 min. After complete dissociation of the cells, $21 \mathrm{ml}$ of medium containing foetal bovine serum (FBS) was added to inactivate the trypsin. The suspension was collected and centrifuged at $200 \mathrm{~g}$ for $5 \mathrm{~min}$. The supernatant was removed, and the pellet was resuspended in $10 \mathrm{ml}$ fresh FBS-containing medium. Cell suspension $(20 \mu \mathrm{l})$ was mixed with $20 \mu \mathrm{l}$ of trypan blue and counted in the Neubauer haemocytometer chamber. Trypan blue enters cells that have damaged cell membranes but are excluded from intact cells; this allows differentiation between living and dead cells. The total number of living cells was calculated as follows: cell number in 8 chambers square $/ 8 \times 2$ (trypan blue dilution factor $) \times 10(10 \mathrm{ml}$ cell suspension) $\times 10000$ (factor from $0.1 \mu \mathrm{l}$ to $1 \mathrm{ml}$ ). The number of cells was used to prepare an appropriate dilution of the cell suspension. 


\subsubsection{Cell viability assay}

The viability of cells under treatment was assessed by the metabolic conversion of 3-(4.5-dimethylthiazol-2-yl)-2.5-diphenyl tetrazolium-bromide (MTT) to a water-insoluble purple formazan dye. Schematic representation of the viability assay is shown in Figure 1. The cells were seeded into 96 -well-plates at a final concentration of $15 \times 10^{3}$ cells/well. The cells were incubated for $24 \mathrm{~h}$ to allow attachment to the well surface. After medium removal, the cells were washed once with $37^{\circ} \mathrm{C}$ PBS. Fresh medium was added, and the cells were treated with different concentrations of drugs diluted in $100 \mu \mathrm{l}$ of FBS-free medium. We tested the following drug concentrations: VPA $2 \mathrm{mM}, 5 \mathrm{mM}, 10 \mathrm{mM}$; TCA $250 \mu \mathrm{M}, 500 \mu \mathrm{M}$, $1000 \mu \mathrm{M}$; riluzole $25 \mu \mathrm{M}, 50 \mu \mathrm{M}, 75 \mu \mathrm{M}$; and TMZ $200 \mu \mathrm{M}$ as well as their combinations. We used a medium containing double distilled water $\left(\mathrm{ddH}_{2} \mathrm{O}\right)$ or DMSO as a control treatment. On subsequent days, $10 \mu \mathrm{l}$ of appropriate $10 \times$ drug solution was added to each well. The treatment was repeated every day for $72 \mathrm{~h}$. After $72 \mathrm{~h}$, MTT was added and incubated for a further $4 \mathrm{~h}$ at $37^{\circ} \mathrm{C}$. A $100 \mu \mathrm{l}$ volume of solubilisation solution $(10 \%$ Triton$\mathrm{X} 100$ in acidic isopropanol $[0.1 \mathrm{~N} \mathrm{HCl}])$ was added to each well to dissolve the formazan crystals. Sample absorbances were measured with a spectrophotometer (Bio-TEK, Winooski, USA) at $562 \mathrm{~nm}$.

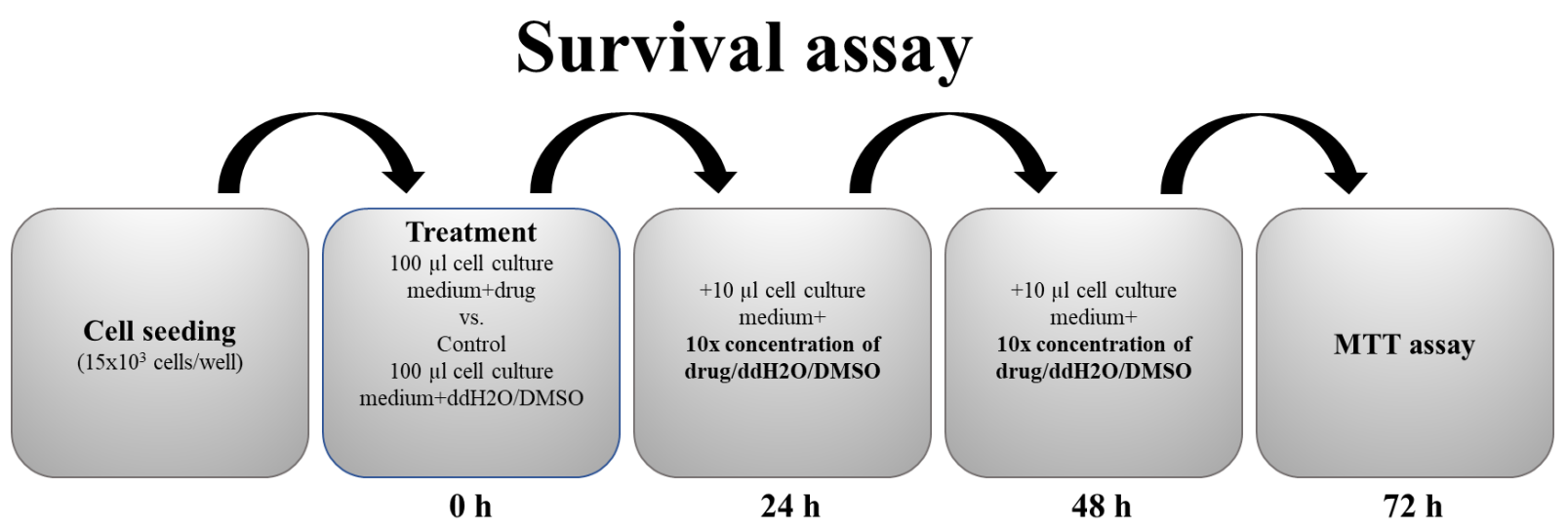

Figure 1. Schematic representation of the survival assay.

For a combined treatment with irradiation and drug application (mimicking the typical radiochemotherapy treatment), the cells were pretreated with drugs/combinations as above for $24 \mathrm{~h}$ and then irradiated at $5 \mathrm{~Gy}$ and $10 \mathrm{~Gy}$ with a Siemens RS225A X-Ray Research System (Figure 2). A control 96-well plate was not irradiated. After irradiation, the cell cultures were treated for a further $48 \mathrm{~h}$ with appropriate drug solutions. After $72 \mathrm{~h}$, the MTT assay was performed as described above in Section 2.2.2. 


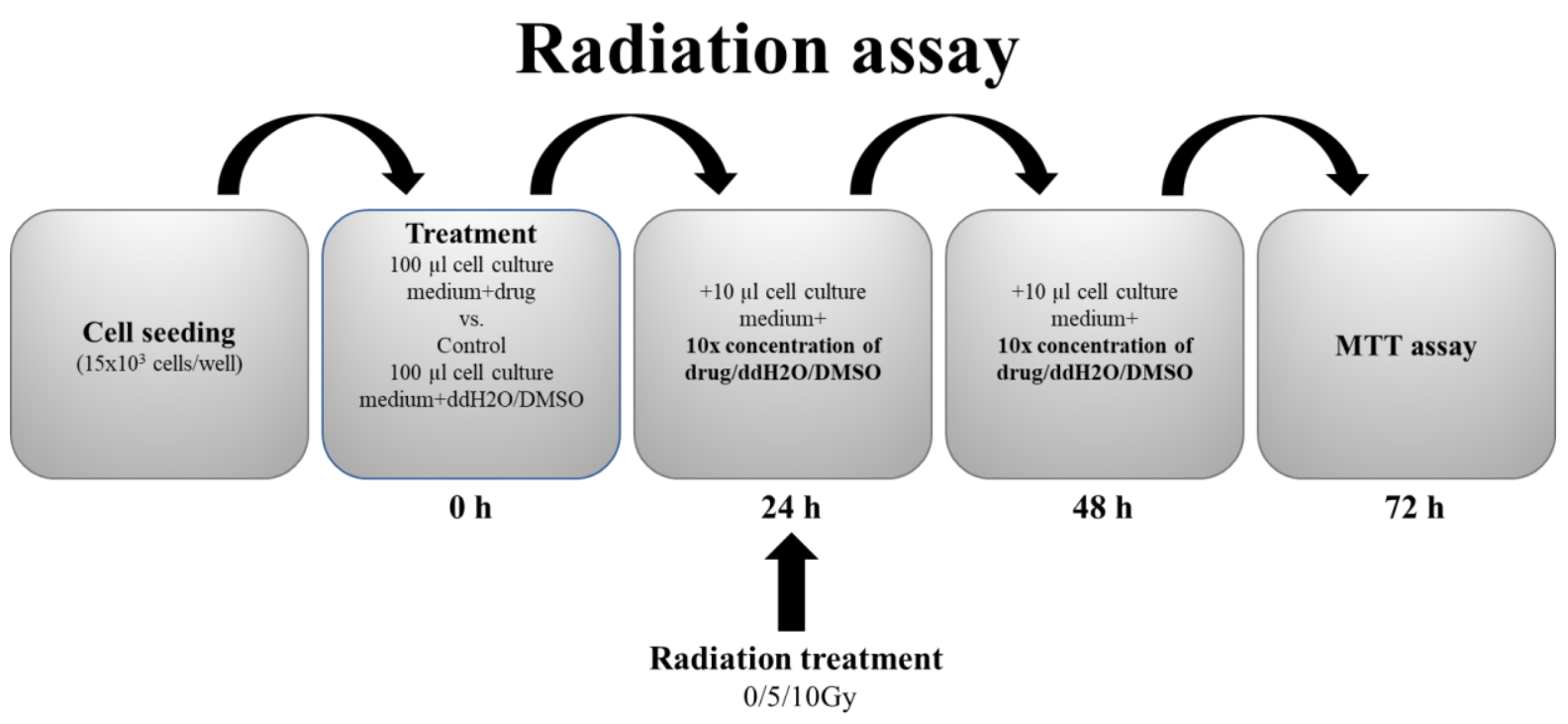

Figure 2. Schematic representation of the in vitro chemoradiation assay

\subsubsection{Proliferation assay}

Cell proliferation was analysed by Ki67 immunohistochemical staining. Ki67 is a protein marker for cell division. This protein can be found in the cell nucleus, and it is localised on the surface of the chromosomes during mitosis (reviewed in Scholzen and Gerdes 2000).

The cells were seeded in three replicates at $1.2 \times 10^{5}$ cells/well in 24 -well plates containing poly-D-lysine-coated glass coverslips. The cells were incubated for $24 \mathrm{~h}$ to allow attachment to the coverslips. The medium was removed, the cells were washed once with $37^{\circ} \mathrm{C} \mathrm{PBS}$ and then $500 \mu \mathrm{l}$ of FBS-free medium containing drug combination was added. After $24 \mathrm{~h}$ cultivation, the cells were fixed with acetone for $20 \mathrm{~min}$ at $-20^{\circ} \mathrm{C}$.

\subsubsection{Immunohistochemical staining}

After fixation, the coverslips were blocked with $10 \%$ horse serum for $20 \mathrm{~min}$, incubated with anti-Ki67 primary antibody (1:50) overnight at $4{ }^{\circ} \mathrm{C}$ and visualised with Alexa 488 Fluor donkey anti-mouse secondary antibody (1:500). Nuclei were counterstained with DAPI. The coverslips were dried at room temperature and mounted with Aqua polymounting medium. Slides were examined with a ZEISS Axiovert 200 fluorescence microscope. Ki-67 positive cells were counted at $20 \times$ resolution. Quantification was performed using Neurolucida software (MBF Bioscience). For each treatment, at least five random microscopy fields were quantified. Each treatment was repeated at least three times. 


\subsubsection{RNA Isolation}

The cells were seeded at $3 \times 10^{5}$ cells/well in 6-well-plates. The cells were incubated for $24 \mathrm{~h}$ to allow attachment and then treated with $2 \mathrm{ml} \mathrm{FBS}$-free-medium containing the test drug(s), as described above in Section 5.2.2. After $24 \mathrm{~h}$, the medium was removed, the cells were washed with cold PBS and $700 \mu$ of QIAzol was added. The cells were scraped from the wells, mixed and then stored at $-80^{\circ} \mathrm{C}$ until needed for further procedures.

The frozen cell pellets were slowly defrosted on ice and homogenised with a Qiagen tissue lyser after the addition of stainless-steel beads $(7 \mathrm{~mm})$. The resulting suspension was further homogenised by passage through $23 \mathrm{G}$ and $27 \mathrm{G}$ syringe needles and incubated for $5 \mathrm{~min}$ at room temperature. The RNA was isolated with a miRNAeasy kit as follows: $140 \mu \mathrm{l}$ of chloroform was added to a sample in an Eppendorf tube and incubated for 2-3 min at room temperature. The tube was centrifuged at $6701 \times \mathrm{g}$ for $15 \mathrm{~min}$ at $4^{\circ} \mathrm{C}$. The aqueous phase was transferred to a new collection tube and diluted with 1.5 volumes of $100 \%$ ethanol. A $700 \mu \mathrm{l}$ volume of the solution was pipetted into the RNeasy Mini column and centrifuged at $6701 \times \mathrm{g}$ for $1 \mathrm{~min}$ at room temperature. The flow-through was discarded, and $700 \mu \mathrm{RWT}$ buffer was added onto the column. The solution was again centrifuged at $6701 \times \mathrm{g}$ for $1 \mathrm{~min}$ at room temperature, and the remaining flow-through was discarded. In the next two steps, the $500 \mu \mathrm{l}$ of RPE buffer was added to the column and centrifuged at $6701 \times \mathrm{g}$ for 1 and 2 min. The RNeasy Mini column was then transferred to a new collection tube, $30 \mu \mathrm{l}$ of RNase-free water was applied to the column and the tube was centrifuged again at $6701 \times \mathrm{g}$ for 2 min. The flow-through containing the RNA sample was diluted 1:25 with $\mathrm{ddH}_{2} \mathrm{O}$, and the RNA concentration was measured in an Eppendorf BioPhotometer Plus. The samples were stored at $-80^{\circ} \mathrm{C}$.

\subsubsection{Quantitative real-time PCR}

RNA $(1 \mu \mathrm{g})$ was reverse transcribed into cDNA with the SuperScript III first-strand synthesis kit. The cDNA (100 ng) was mixed with SYBR-Green Mastermix and the two TFPI2 gene primers (5 pmol). Real-time PCR amplification was performed in a BioRAD CFX384 cycler. The amplification was carried out with $15 \mathrm{~s}$ denaturation at $95^{\circ} \mathrm{C}$ for $15 \mathrm{~s}$ and $30 \mathrm{~s}$ extension at $60^{\circ} \mathrm{C}$ with 40 cycles. The data were normalised to the mean of 2 housekeeping genes hydroxymethylbilane synthase (HMBS) and hypoxanthine phosphoribosyltransferase 1 (HPRT1). 


\subsubsection{Cell invasion assay}

Cell invasion was examined with the xCELLigence system using 16-well cell invasion/migration (CIM-16) plates. At $16 \mathrm{~h}$ before the experiment, U87MG cells were serum-starved. The upper chamber (UC) of the CIM plates was coated with $20 \mu \mathrm{l}$ of an $800 \mu \mathrm{g} / \mathrm{ml}$ solution of Matrigel ${ }^{\mathrm{TM}}$ and left for $4 \mathrm{~h}$ in the incubator for polymerisation. Next, $5 \times 10^{4}$ cells were seeded in each well of the UC in serum-free media containing the test compounds. Culture medium including $5 \%$ FBS and the test compounds were added to each well of the lower chamber. The bottom side of the upper chamber was coated with microelectrode sensors. When cells adhered to these sensors, the electric current was reduced. This impedance value of each well was automatically monitored by the $\mathrm{xCELLigence} \mathrm{system} \mathrm{for} \mathrm{the} 4 \mathrm{~h}$ duration of the experiment and was expressed as the Cell Index (CI).

\subsubsection{Statistical analysis}

Statistical analysis was performed with Statistica software (TIBCO Software Inc.) and GraphPad Prism (GraphPad). The treatment and control groups were compared with 2 -sided unpaired Student`s t-test. The level of significance was set at $\mathrm{p}<0.05$. 


\section{$3 \quad$ Results}

\subsection{Effect of single drug treatment on cell viability}

We studied the effect of VPA, TCA and riluzole, applied singly, on U87MG in the MTT cell viability assay. These experiments used the following concentrations: 2, 5 and $10 \mathrm{mM} \mathrm{VPA}$; 250, 500 and $1000 \mu \mathrm{M}$ TCA; and 25, 50 and $75 \mu \mathrm{M}$ riluzole.
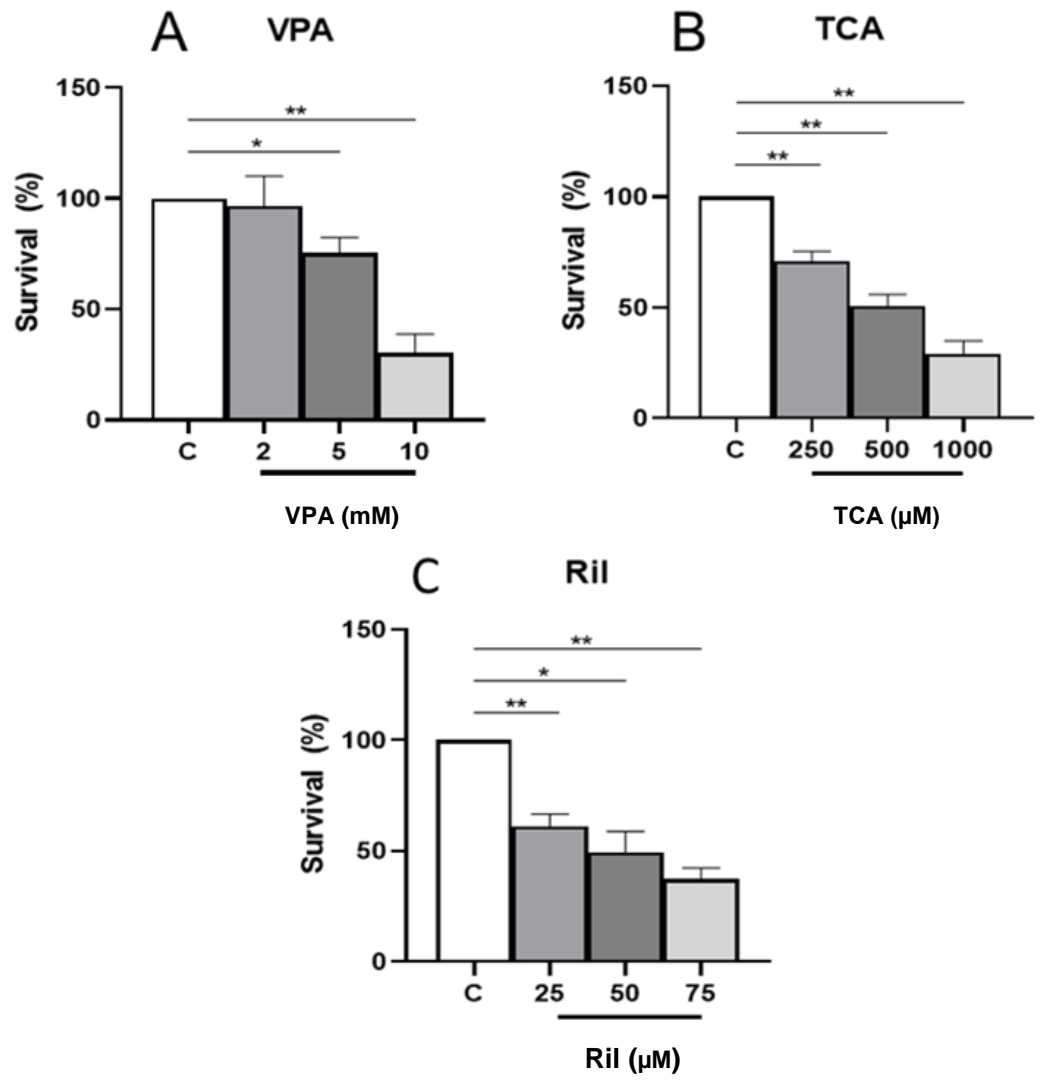

Figure 3. MTT assays for U87MG cell viability after single treatments with (A) valproic acid (VPA), (B) tranylcypromine hydrochloride (TCA), and (C) riluzole hydrochloride (Ril). Data are the mean \pm standard error mean (SEM). Significantly different at: $*=p<0.05$, $* *=p<0.01$, and $* * *=p<0.001$. C: Control.

Valproic acid at $5 \mathrm{mM}$ and $10 \mathrm{mM}$ had a significant effect on cell survival compared to the control condition. Cell survival was $75.4 \%$ with $5 \mathrm{mM}(\mathrm{p}=0.03)$ and $30.3 \%$ with $10 \mathrm{mM}$ VPA $(p=0.005)$ according to the MT'T assay-(Figure 3A).

All concentrations of TCA significantly reduced U87MG cell viability (Figure 3B). Cell survival was $70.9 \%$ with $250 \mu \mathrm{M}$ TCA ( $p=0.008), 50.7 \%$ with $500 \mu \mathrm{M}$ TCA $(\mathrm{p}=0.004)$ and $29.2 \%$ with $1000 \mu \mathrm{M}$ TCA $(\mathrm{p}=0.002)$. 
Riluzole treatment had a significant effect on U87MG cell viability (Figure 3C). Cell survival was $60.9 \%$ with $25 \mu \mathrm{M}$ riluzole $(\mathrm{p}=0.007), 49.4 \%$ with $50 \mu \mathrm{M}$ riluzole $(\mathrm{p}=0.001)$ and $37.1 \%$ with $75 \mu \mathrm{M}$ riluzole $(\mathrm{p}=0.002)$.

\subsection{Effect of the combination treatment on cell viability}

The effect of combinations of VPA $(2,5$ and $10 \mathrm{mM})$ and riluzole $(25$ and $50 \mu \mathrm{M})$ were tested on U87MG cell viability (Figure 4A). The greatest effect on the cell survival was achieved with the combination of $10 \mathrm{mM} \mathrm{VPA}$ and $50 \mu \mathrm{M}$ riluzole $(22.2 \%, \mathrm{p}=0.001)$ and with $10 \mathrm{mM}$ VPA and $25 \mu \mathrm{M}$ riluzole $(24.0 \%, \mathrm{p}=0.001)$. The least potent combination was $2 \mathrm{mM}$ VPA with $25 \mu \mathrm{M}$ riluzole $(57.8 \%, \mathrm{p}=0.017)$. The combinations of riluzole with $10 \mathrm{mM}$ VPA were significantly better than the single treatment with riluzole, but not with single VPA treatments. All combinations of riluzole with $2 \mathrm{mM}$ and $5 \mathrm{mM}$ VPA had a significantly larger effect on survival than did treatments with VPA alone, but not with riluzole alone (Table 2).

Combinations of TCA $(250$ and $500 \mu \mathrm{M})$ and riluzole $(25$ and $50 \mu \mathrm{M})$ were then tested (Figure 4B). The greatest effect for the TCA and riluzole pair was achieved with $500 \mu \mathrm{M}$ TCA and $50 \mu \mathrm{M}$ riluzole $(25.3 \%$ survival, $\mathrm{p}=0.001)$. A comparable effect was produced by $250 \mu \mathrm{M}$ TCA and $50 \mu \mathrm{M}$ riluzole $(29.9 \%$ survival, $\mathrm{p}=0.002)$ and $500 \mu \mathrm{M}$ TCA and $25 \mu \mathrm{M}$ riluzole $(29.3 \%$ survival, $\mathrm{p}=0.001)$. The least effective but still significant combination was $250 \mu \mathrm{M}$ TCA and $25 \mu \mathrm{M}$ riluzole $(35.96 \%$ survival, $\mathrm{p}=0.003)$. All combinations produced a significantly higher effect compared to single treatments of either TCA or riluzole (Table 2). 

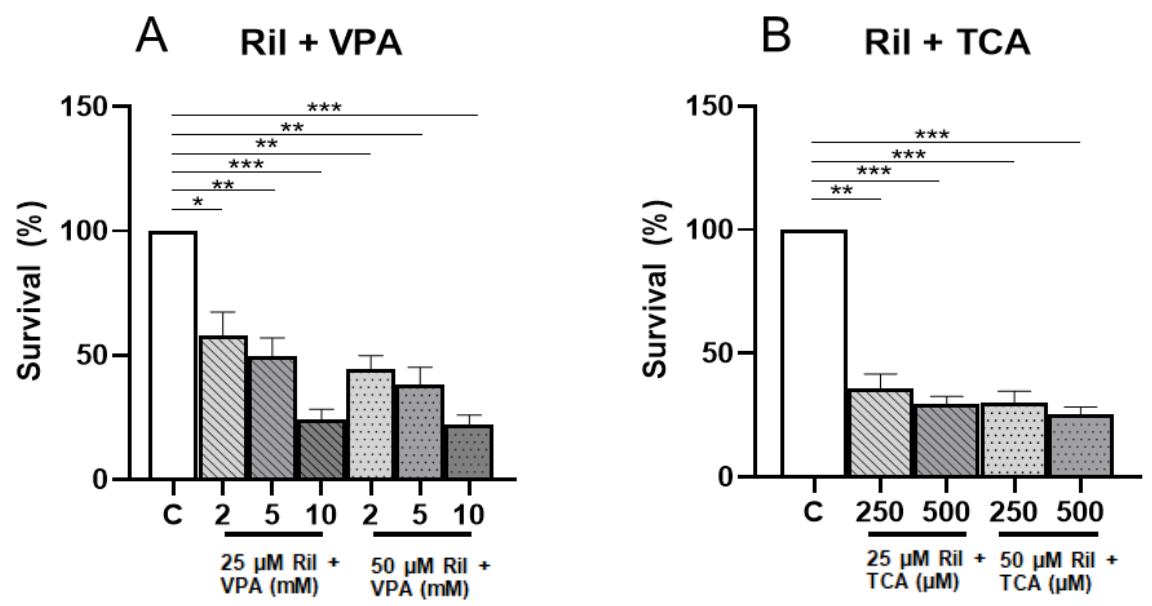

C TCA + VPA

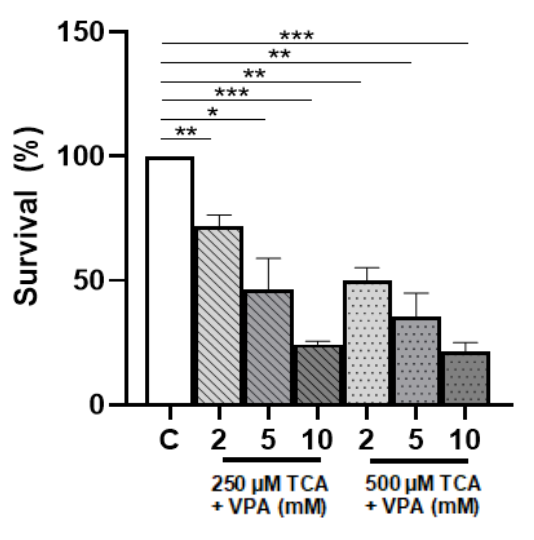

Figure 4. MTT assays for U87MG cell viability after combination treatment with (A) riluzole (Ril)+ valproic acid (VPA), (B) riluzole + tranylcypromine hydrochloride (TCA), and (C) TCA + VPA. Data are the mean \pm SEM. Significantly different at: * $=p<0.05$, $* *=\mathrm{p}<0.01$, and $* * *=\mathrm{p}<0.001$. C: Control.

We also evaluated the efficacy of combinations of TCA (250 and $500 \mu \mathrm{M})$ and VPA $(2,5$ and $10 \mathrm{mM}$ ) (Figure 4C). The greatest effect on the cell survival was seen with $10 \mathrm{mM}$ VPA and $500 \mu \mathrm{M}$ TCA $(21.3 \%$ cell survival, $\mathrm{p}=0.001)$ and $10 \mathrm{mM} \mathrm{VPA}$ and $250 \mu \mathrm{M}$ TCA $(24.3 \%, \mathrm{p}<0.0001)$. The least effective combination was $2 \mathrm{mM} \mathrm{VPA}$ and $250 \mu \mathrm{M}$ TCA $(71.6 \%, \mathrm{p}=0.009)$. All combinations were significantly better than the control. Here, again, only the combination of $5 \mathrm{mM} \mathrm{VPA}$ and $250 \mathrm{mM}$ TCA (46.6\% cell survival) was significantly different than both single treatments; no other combinations could produce a significantly better effect than the single treatments (Table 2). 
Table 2. Student`s t-test for single treatment compared to combination treatment.

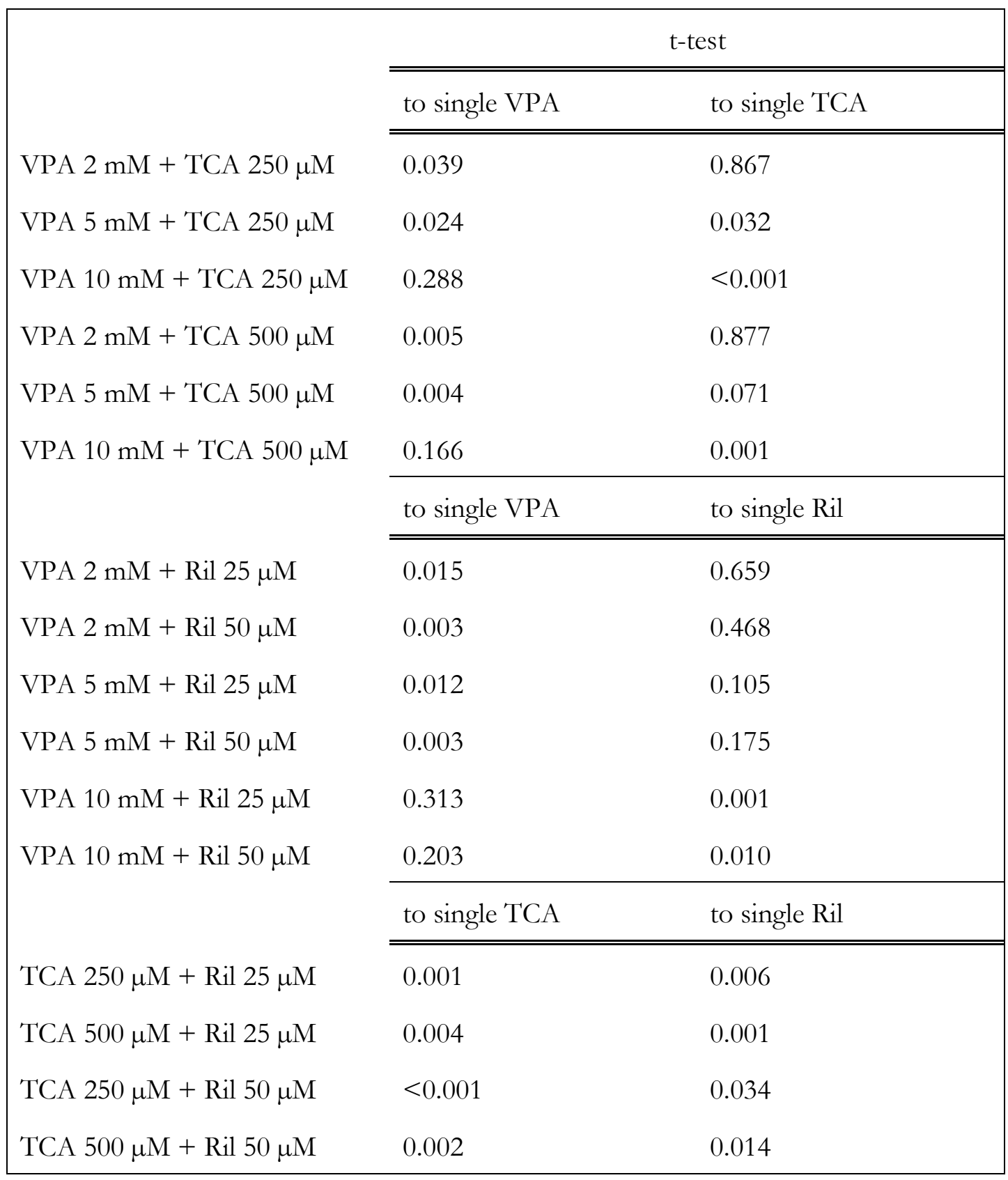

TCA: tranylcypromine hydrochloride. VPA: valproic acid. Ril: riluzole hydrochloride.

The fact that several combinations of VPA and riluzole and of TCA and VPA did not produce a significantly stronger effect than single drugs would mean that the effect strength was primarily attributed to one of the combination partners. 


\subsection{Effect of the combination treatment with temozolomide (TMZ) on cell viability}

Next, we studied the combination effect of TCA, VPA and riluzole with TMZ, the first-line chemotherapy for the treatment of GBM. The following concentrations were chosen: VPA $(2,5$ and $10 \mathrm{mM})$, TCA $(250,500 \mu \mathrm{M})$, riluzole $(25$ and $50 \mu \mathrm{M})$ and $200 \mu \mathrm{M}$ TMZ.
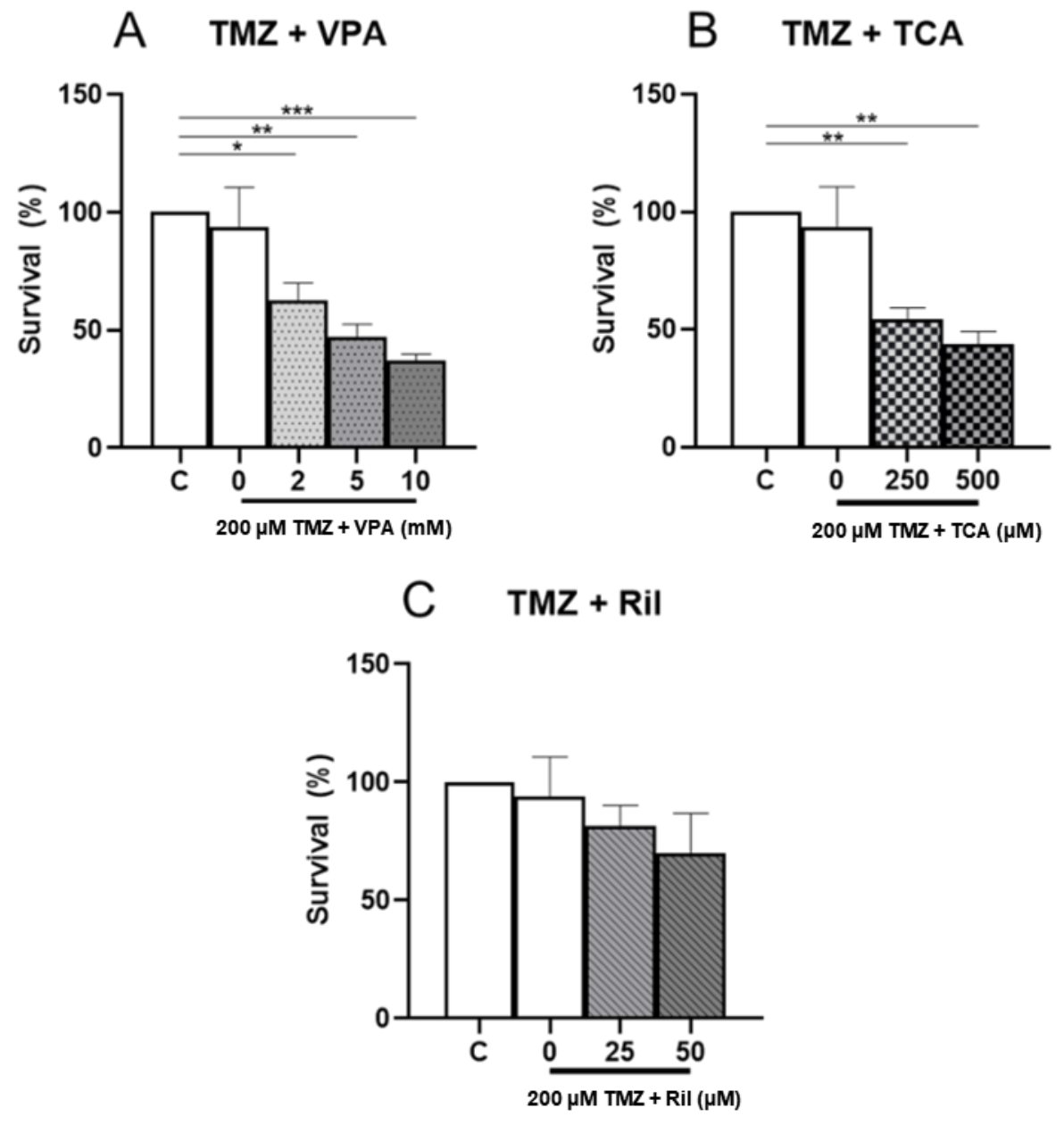

Figure 5. MTT assays for U87MG viability after combination treatment between (A) valproic acid (VPA), (B) tranylcypromine hydrochloride (TCA), (C) riluzole hydrochloride (Ril) with temozolomide (TMZ). Data are the mean \pm SEM. Significantly different at: $*=p<0.05$, $* *=\mathrm{p}<0.01$, and $* * *=\mathrm{p}<0.001$. C: Control.

TMZ applied singly as a treatment failed to produce a significant effect on cell survival (93.8 \%, $\mathrm{p}=0.43$ ). TMZ in combination with 2, 5 and $10 \mathrm{mM} \mathrm{VPA} \mathrm{(Figure} \mathrm{5A)} \mathrm{led} \mathrm{to}$ $62.6 \%, 46.9 \%$ and $37.3 \%$ cell survival $(\mathrm{p}<0.001)$, respectively. In combination with 250 and $500 \mu \mathrm{M}$ TCA (Figure 5B), TMZ treatment led to $54.5 \%$ and $43.9 \%$ cell survival $(\mathrm{p}<0.001)$ and with 25 and $50 \mu \mathrm{M}$ riluzole (Figure 5C), TMZ treatment led to $81.3 \%$ and 
$69.9 \%$ cell survival $(\mathrm{p}<0.05)$. No significant difference was noted between TMZ applied singly or in combination with $25 \mu \mathrm{M}$ and $50 \mu \mathrm{M}$ riluzole, whereas the other combinations were significantly better compared than TMZ treatment alone.

\subsection{Effect of combination treatment with radiation on cell viability}

We tested the effect of VPA, TCA and riluzole in combination with radiation therapy (Figure 6). Radiation doses applied to the GBM cell cultures in previous studies varied between 2-30 Gy (Hosein et al. 2015), but the most commonly used doses were below 10 Gy. In this study, we chose radiation doses of 5 Gy and $10 \mathrm{~Gy}$.
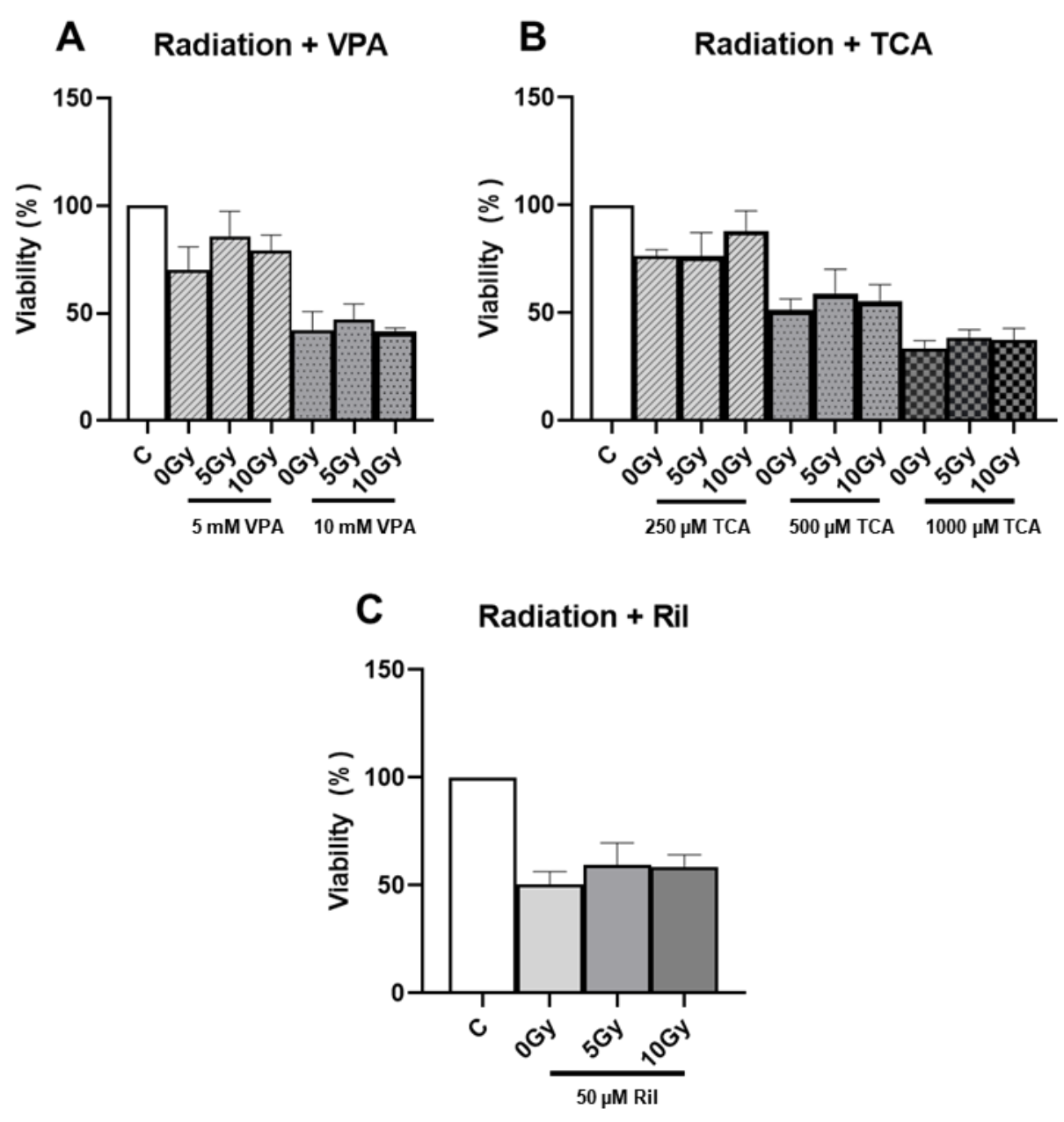

Figure 6. MTT assays for U87MG viability after combining radiation and (A) valproic acid (VPA), (B) tranylcypromine hydrochloride (TCA), (C) riluzole hydrochloride (Ril). Data are the mean \pm SEM. Significantly different at: $*=p<0.05,{ }^{* *}=p<0.01$, and ${ }^{* * *}=p<0.001$. C: Control. 
Cell cultures were treated with 5 and $10 \mathrm{mM} \mathrm{VPA} ; 250,500$ and $1000 \mu \mathrm{M}$ TCA or $50 \mu \mathrm{M}$ riluzole $24 \mathrm{~h}$ before the application of radiation (5 Gy and $10 \mathrm{~Gy}$ ) and then for the next $48 \mathrm{~h}$ after the radiation treatment. The MTT assay showed no significant difference $(\mathrm{p}>0.05)$ between cells radiated with $10 \mathrm{~Gy}$ or $5 \mathrm{~Gy}$, or the control group, as well as no significant difference between $10 \mathrm{~Gy}$ and $5 \mathrm{~Gy}$ in combination with any of the drugs (Figure 6A, B, C).

\subsection{Inhibition of GBM cell proliferation by combined drug treatment}

Glioblastoma is characterised by a high rate of proliferation and aggressive invasion of normal brain tissue. The effects of 5 and $10 \mathrm{mM}$ VPA, 250 and $500 \mu \mathrm{M}$ TCA and 25 and 50 $\mu \mathrm{M}$ riluzole and their combinations on the proliferation of U87MG cells were studied by Ki67 immunofluorescence staining (Figure 7A). Student`s t-test showed a significant reduction in the number of proliferating cells following the treatment with $5 \mathrm{mM} \mathrm{VPA}(13 \%$, $\mathrm{p}=0.04)$ and $500 \mu \mathrm{M}$ TCA $(12 \%, \mathrm{p}=0.01)$ and the combination of $5 \mathrm{mM}$ VPA and 500 $\mu \mathrm{M}$ TCA $(3.4 \%, \mathrm{p}<0.01)$ (Figure $7 \mathrm{~B})$. 
A

\section{Control VPA Ril TCA}

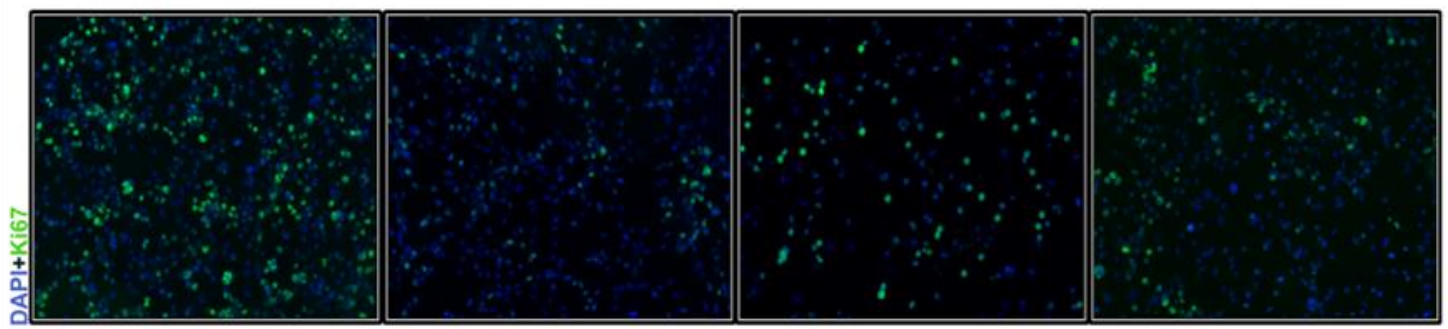

\section{Control VPA+Ril Ril+TCA TCA+VPA}

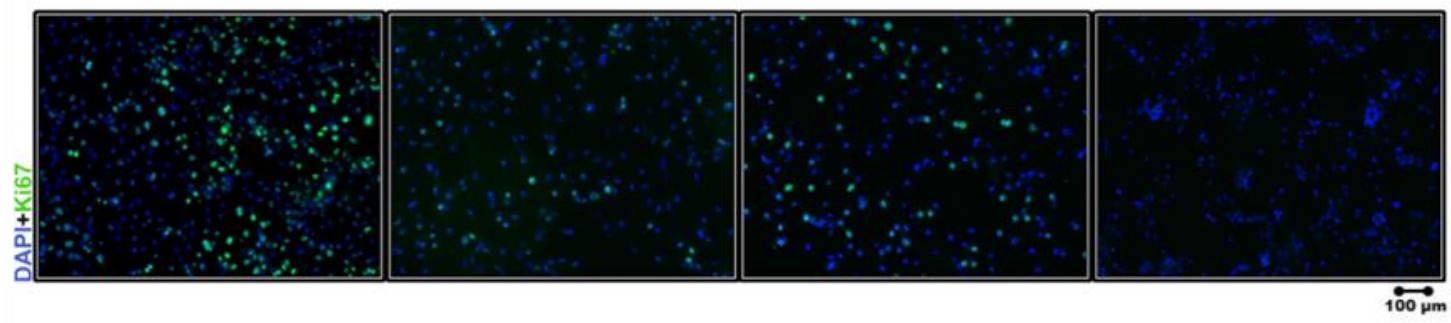

B

Proliferation

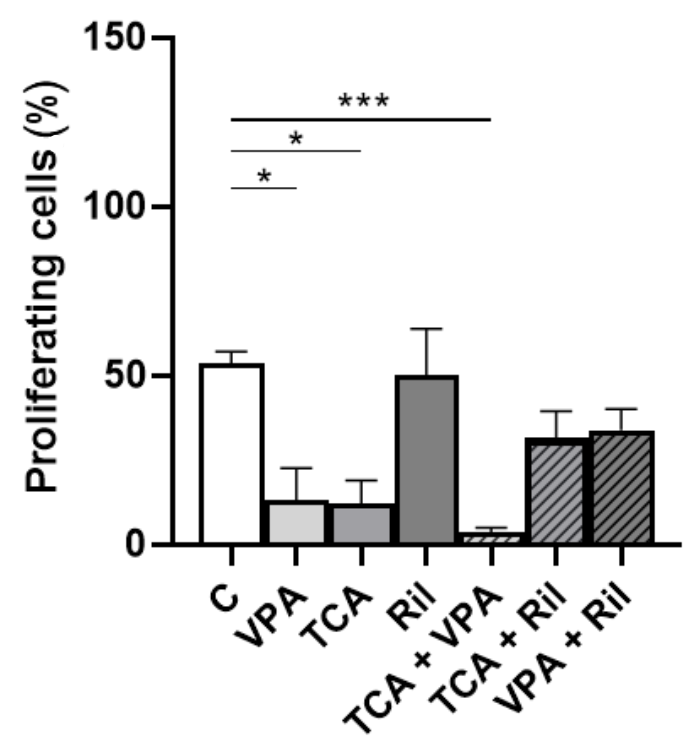

Figure 7. Beneficial effects of combined treatment on proliferation of U87MG cells. (A) Images showing immunohistochemical staining with Ki-67 antibody. Cells were stained with anti-Ki67 (green). Nuclei were counterstained with 4',6-diamidino-2-phenylindol (DAPI) (blue, 10× magnification). (B) Diagrams showing the proliferation of U87MG cells under treatment with $5 \mathrm{mM}$ valproic acid (VPA), $500 \mu \mathrm{M}$ tranylcypromine hydrochloride (TCA), and $50 \mu \mathrm{M}$ riluzole hydrochloride (Ril) and their combinations. Significantly different at: $*=\mathrm{p}<0.05$, and $* *=\mathrm{p}<0.01$. 


\subsection{Effect of single or combination treatment on TFPI2 gene expression and cell invasion}

The important tumour suppressor role of TFPI 2 in cancer and the cancer microenvironment and evidence for epigenetic regulation of coagulation system members led us to analyse the effect of TCA, VPA and riluzole on the expression of the TFPI2 gene in U87MG cells (Figure 8). The cells were treated with $500 \mu \mathrm{M}$ TCA, $50 \mu \mathrm{M}$ riluzole and $5 \mathrm{mM} \mathrm{VPA}$, either as single agents or in combinations. A significant upregulation of TFPI2 was observed after the treatment with $5 \mathrm{mM}$ VPA $(2.5$-fold, $\mathrm{p}=0.04), 50 \mu \mathrm{M}$ riluzole $(3.2$-fold, $\mathrm{p}=0.04)$ and all combination treatments: $5 \mathrm{mM} \mathrm{VPA}$ and $50 \mu \mathrm{M}$ riluzole (4.8-fold, $\mathrm{p}=0.03), 500 \mu \mathrm{M}$ TCA and $50 \mu \mathrm{M}$ riluzole (3.8-fold, $\mathrm{p}=0.01$ ) and $5 \mathrm{mM}$ VPA and $500 \mu \mathrm{M}$ TCA (4-fold, $\mathrm{p}=0.05$ ).

\section{TFPI2 gene expression}

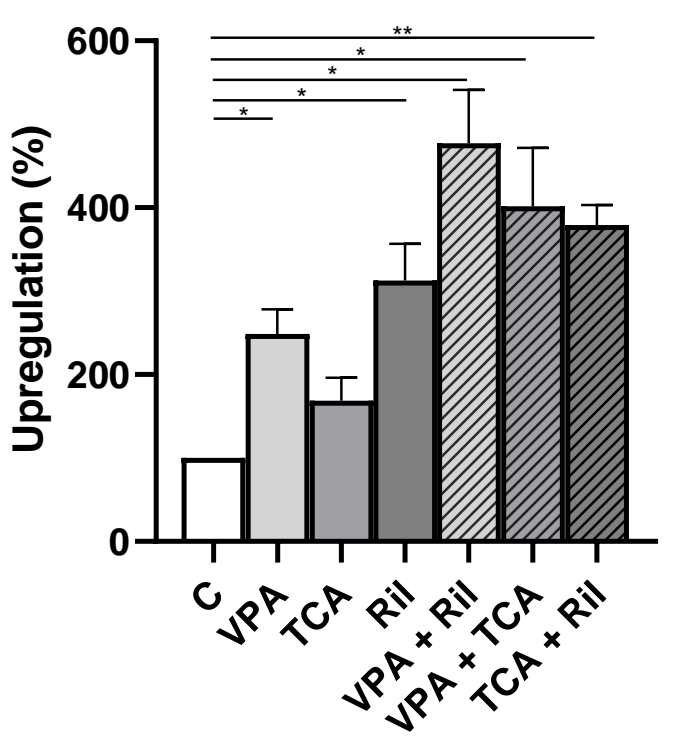

Figure 8. Expression of tissue factor pathway inbibitor 2 (TFPI2) in U87MG cells treated with valproic acid (VPA), tranylcypromine hydrochloride (TCA) and riluzole hydrochloride (Ril). Data are the mean \pm SEM. Significantly different at: $*=p<0.05, * *=p<0.01$, and $* * *=p<0.001$. C: Control. 
A

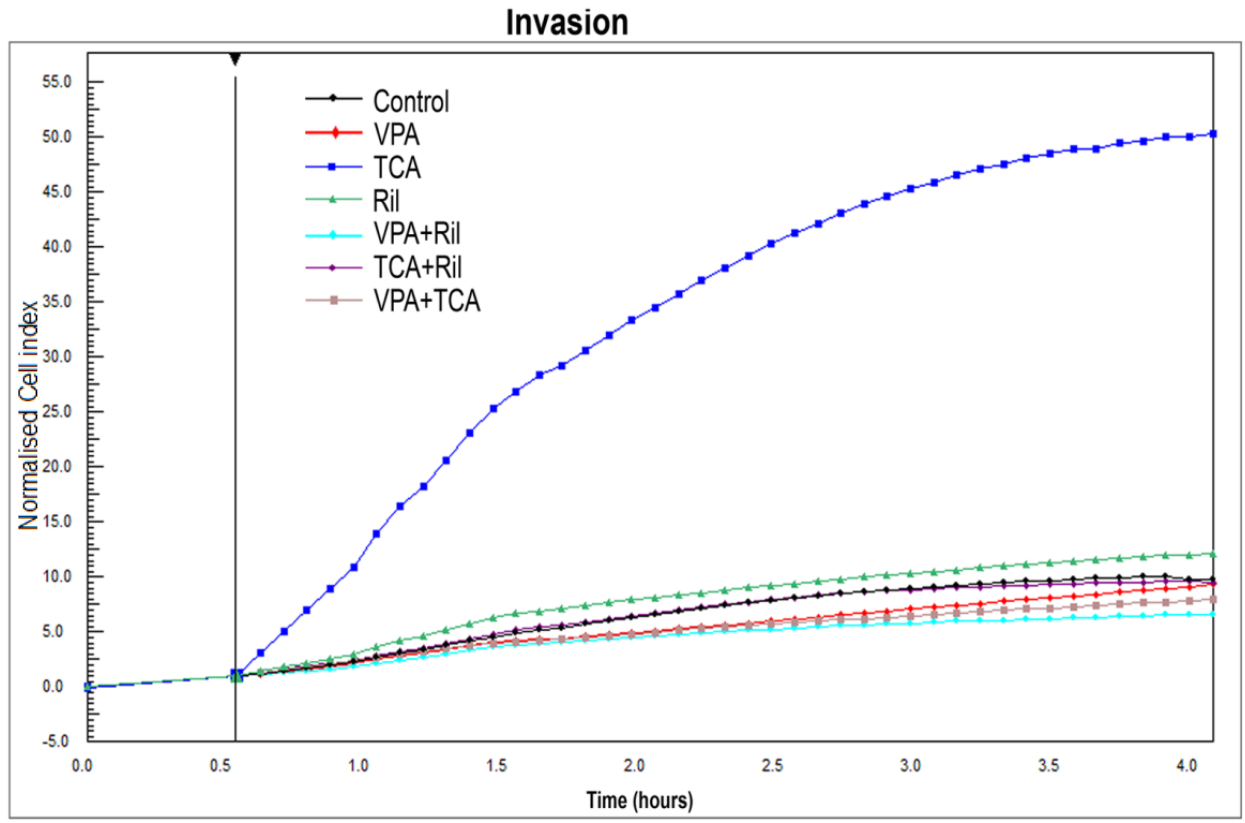

B

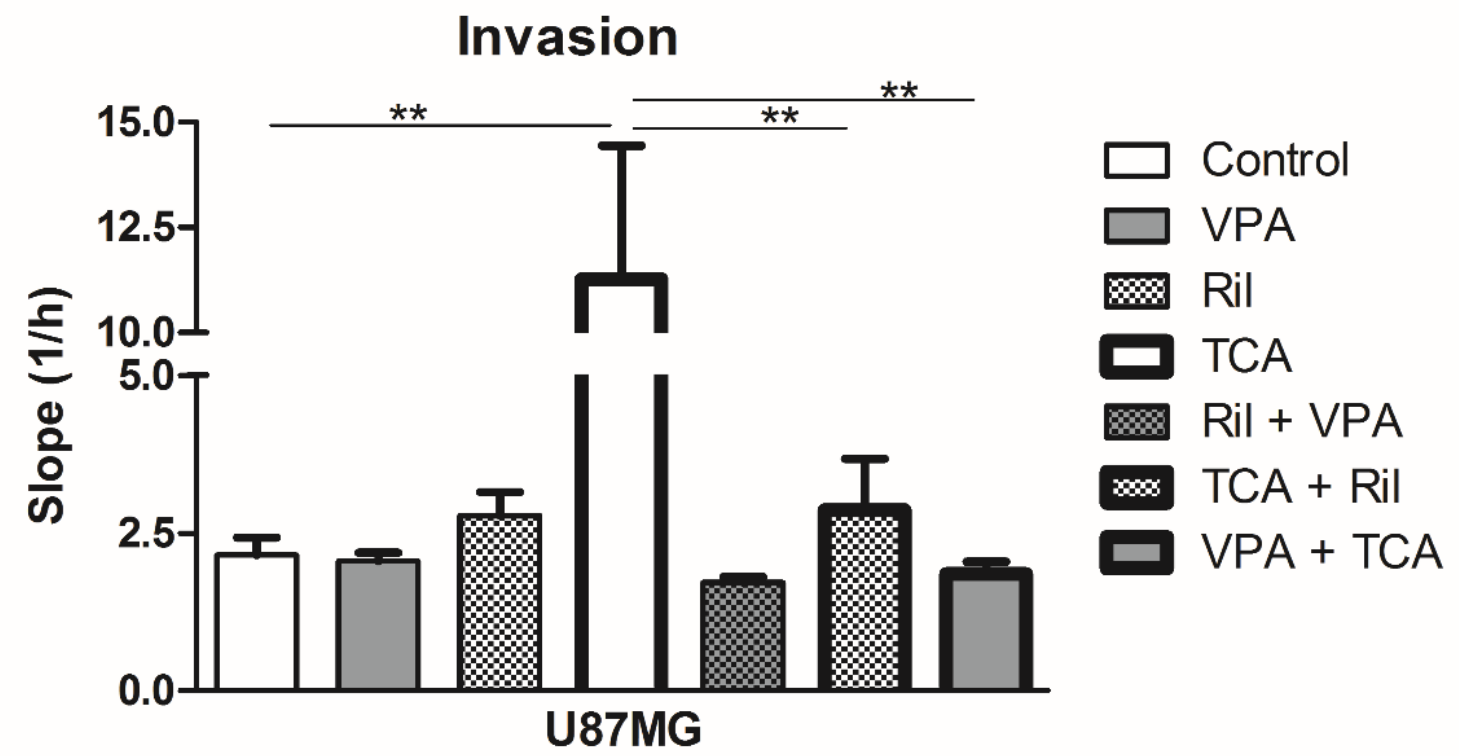

Figure 9. Effects of combined treatment on the invasiveness of U87MG cells. (A) The invasion rate of cells was monitored with the xCELLigence system $(0-4 \mathrm{~h})$. Data are the mean \pm SEM. (B) Real-time monitoring of cell invasion, representative picture. Significantly different at: $*=\mathrm{p}<0.05, * *=\mathrm{p}<0.01$, and $* * *=\mathrm{p}<0.001$. TCA: tranylcypromine hydrochloride. VPA: valproic acid. Ril: riluzole hydrochloride. 
Since TFPI2 is also involved in ECM remodelling and cellular invasion during cancer progression (Lai et al. 2014), we examined the invasion effect under these combined treatments. High invasive potential of GBM cells is one of the reasons for rapid tumour progression (Kegelman et al. 2017). Reduction of invasion (Figure 9) was observed when comparing TCA treatment alone and the combination of VPA and TCA or riluzole and TCA. Even though not statistically significant, a slightly reduced invasion was detected comparing riluzole alone with the combination of VPA and riluzole. 


\section{Discussion}

The great molecular heterogeneity of GBM is the key to its high radio- and chemoresistance. The number of experimental studies and clinical trials arguing for combination treatment is growing rapidly. The simultaneous utilisation of various classes of drugs directed against different oncogenic pathways could produce a synergetic effect on tumour cells with a heterogeneous genetic background. In this work, we examined the effects of combination treatments with VPA, TCA and riluzole on the U87MG GBM cell line.

\subsection{Effect of single VPA, TCA and riluzole treatments}

Although with a different response, all three tested drugs - VPA, TCA or riluzole - had a significant effect on the viability of U87MG cells.

The treatment with $10 \mathrm{mM}$ VPA reduced cellular viability by nearly two thirds after $72 \mathrm{~h}$ of treatment. These results are in a line with already published data. The IC20, IC50 and IC80 values for VPA were 1.8-2.8, 3-5.2 and 6-9 $\mathrm{mM}$ after $72 \mathrm{~h}$ treatment in different cell cultures (Das et al. 2007). In another study, treatment with $7.5 \mathrm{mM}$ VPA for $36 \mathrm{~h}$ reduced proliferation by up to $50 \%$ (Hoja et al. 2016). In preclinical trials, VPA showed its effectiveness in cell cultures and xenograft tumour models via the induction of differentiation, apoptosis, cell-cycle arrest and increased oxidative stress (Zhang $\mathrm{C}$ et al. 2016).

The antineoplastic effect of the epigenetic modulator VPA, which is used as an antiepileptic agent in patients with malignant gliomas, has been widely discussed. A retrospective study demonstrated that overall survival is longer in patients treated with VPA than in patients on other antiepileptic drugs (16.9 vs 13.6 months) (Barker et al. 2013). In a series of 108 GBM patients with symptomatic epilepsy, patients receiving VPA showed a median survival of 69 weeks (95\% CI, 61.7-67.3 weeks) vs 61 weeks (95\% CI, 52.5-69.5 weeks) in the control group (Kerkhof et al. 2013). Despite promising results in retrospective trials, the data from prospective clinical trials on HDAC inhibitors in GBM are contradictory. Although the combination of vorinostat and bortezomib showed a synergistic effect in GBM cell cultures (Yu et al. 2008), the Phase II trial revealed no benefit of the treatment in recurrent GBM (Friday et al. 2012). The data from the EORT/NCIC trial for newly diagnosed GBM showed that patients receiving VPA had better survival than patients treated with another antiepileptic drug or patients without antiepileptic therapy (Weller et al. 2011). However, a 
pooled analysis of several randomised controlled trials (AVAGlio, CENTRIC, CORE and RTOG 0825) failed to show any improved PFS or OS for patients under the antiepileptic treatment with VPA (Happold et al. 2016). The phase II trial of VPA with standard radioand chemotherapy led to a median overall survival of 29.6 months and progression-free survival of 10.5 months, which exceeded survivals obtained by standard regimens (Krauze et al. 2015). Further studies are needed to identify patient groups with susceptibility for the treatment with HDAC inhibitors, as well as to characterise molecular markers associated with positive responses to these agents.

The treatment with TCA significantly reduced in the viability of U87MG cells. The mechanism of the TCA effect on cell death was not analysed in this study. Tranylcypromine is an unspecific inhibitor of LSD1 that is known to regulate the activity of various cancerrelated transcription factors and nuclear receptors, such as c-myc (Kozono et al. 2015), the retinoic acid receptor (Schenk et al. 2012b) and p53 (Huang et al. 2007). Lysine-specific demethylase 1 regulates the DNA damage-induced cell death and takes part in the DNA repair (Kontaki and Talianidis 2010). It also plays an important role in the regulatory program of the GBM stem-like cells and its knockdown leads to the loss of the capacity of tumour cells to initiate tumours in vivo (Suvà et al. 2014b). Knockdown promotes tumorigenesis and invasion of GBM cells via the interaction with the p53 signalling pathway (Yi et al. 2016). Combined treatment with the glutathione scavenger para-quinone methide and TCA led to the induction of apoptosis in several GBM cell cultures (Engel et al. 2018). Conversely, LSD1 lowered TMZ effect on GBM cells under reduced oxygen conditions (Bielecka and Obuchowicz 2016). This shows that the activity of LSD1 inhibitors is complex and could be modulated by different treatment and genetic conditions.

All concentrations of riluzole had a significant effect on U87MG cell death. Even though a wide range of riluzole effects have already been discovered, its tumour-suppressor mechanism is not completely understood. One widely supported hypothesis involves antagonism of the glutamate overproduction in gliomas. The excessive glutamate release is one of the factors promoting the aggressive proliferative growth in GBM via the activation of PI3K/PTEN/AKT and MAPK pathways by the interaction with mGluR (reviewed in Willard and Koochekpour 2013). The PI3K/AKT/mTOR pathway is one of the core tumour-driving pathways in GBM (Brennan et al. 2013) and is over-activated in GBM stemlike cells in vivo (Jhanwar-Uniyal et al. 2011). The pathway is important for tumour neovascularization (Wen et al. 2014). 
The inhibition of glutamate release in U87MG glioblastoma cell line by riluzole leads to the reduction in cell proliferation, invasion and migration, G0/G1 cell cycle arrest and induction of apoptosis (Yelskaya et al. 2013). Riluzole negatively regulated PI3K/AKT/mTOR pathway. Riluzole decreased the phosphorylation of PI3K, Akt, mTOR and P70S6K by the interaction with mGluR1 (Zhang et al. 2015). The combination of riluzole with mTOR inhibition was effective at preventing the tumour progression (Rosenberg et al. 2015). Recently, riluzole was shown to downregulate the glucose transporter 3 (GLUT3) (Sperling et al. 2017), an important protein complex for the tumorigenic potential of radiochemoresistant glioblastoma stem-like cells (Flavahan et al. 2013).

\subsection{Combination treatment}

The combination of repurposed drugs could potentially have a higher effect compared to single drug treatment. In our experiments, the most prominent effect on cell viability was achieved by the combination of $50 \mu \mathrm{M}$ riluzole and $10 \mathrm{mM}$ VPA (22.2\%) and $10 \mathrm{mM}$ VPA and $500 \mu \mathrm{M}$ TCA $(21.3 \%)$. Only a few combinations were significantly better compared to either single treatment. The reason could be that single doses of VPA and TCA were already sufficiently strong to produce a devastating effect on the cells. Quite possibly, a synergistic effect could be achieved at lower doses of the medications.

Different studies have shown a synergistic effect of combined HDAC and LSD1 inhibitors. Lysine-specific demethylase 1 and HDAC class I/II are involved in several transcriptional complexes, such as CoRest (You et al. 2001) and NuRD (Tong et al. 1998), which are known transcriptional repressors and are involved in the development of cancer. The synergistic effect of LSD1 inhibitor SP2509 with HDAC inhibitor panobinostat led to the de-repression of the expression of tumour suppressors protein 21 (p21), protein 27 (p27) and CAATT/enhancer binding protein (C/EBP2) and depleted c-myc expression (Fiskus et al. 2014). In another study, the combination of TCA with vorinostat, panobinostat and entinostat decreased the cancer cell viability, while the drug effect appeared to be dependent on TP53 expression (Singh et al. 2015).

\subsubsection{Radiochemosensitivity}

We showed that the combination of TMZ with VPA, TCA and riluzole increased the effect of conventional chemotherapy with TMZ. All combinations produced a significantly higher 
effect than single TMZ treatment $(p<0.001)$. Conversely, U87MG cells appeared to be radioresistant. We observed no significant effect of 5 and 10 Gy over the control condition.

Several studies have reported additive and synergetic effects of VPA in combination with TMZ and radiation (Hosein et al. 2015). Histone deacetylases can widely influence DNA replication and repair (HR, NHEJ repair). The interaction with the DNA repair system can explain the sensitising effect of HDACi to radiation and classical chemotherapy (Stengel and Hiebert 2015). The combination of riluzole with radiation therapy was more effective than riluzole monotherapy (Khan et al. 2011). This treatment led to a decrease in tumour volume of melanoma brain metastases in a mouse xenograft model when compared with radiation treatment alone.

\subsubsection{Benefits of combined treatment on TFPI 2 expression and invasion}

Taking into account the infiltrative character of GBM, the changes in expression of a gene which inhibits tumour cell migration is undoubtedly a beneficial effect of the combination treatment. The U87MG cells showed a significant upregulation of TFPI2 under the single treatment with VPA or TCA as well as for all combinations of VPA, TCA and riluzole. Moreover, we observed that the combination treatment with VPA and TCA led to significant inhibition of invasion compared to TCA treatment alone. The same effect was observed for the combination of VPA and riluzole. These data are in agreement with previous studies which showed that TFPI2 expression could be regulated by epigenetic mechanisms (Dong et al. 2013). The promoter of this gene is hypermethylated and silenced in $22.2 \%$ of glioblastoma surgical specimens. Patients with unmethylated TFPI2 gene showed better survival than patients with methylated TFPI2 (Vaitkiene et al. 2012). The upregulation of TFPI2 in glioma cells was probably responsible for the decreased invasion in in vitro and in in vivo (Konduri et al. 2001). The direct influence of TFPI2 on the reduction of the invasion was not examined in this study. 


\section{Conclusion}

Even though integrated treatments are implemented in current medical practice, GBM remains one of the most devastating brain tumours. This highlights the urgent need for further research to improve survival and the quality of life in patients with this type of cancer. This study analysed the in vitro effect of VPA, TCA and riluzole, singly and in combination or concert with standard chemo- or radiotherapy treatment, in cultured GBM cells. The rationale behind this study was to target several different pathways in GBM to minimise drug resistance. The positively responding drugs can then be repurposed for GBM treatment.

Treatment of U87MG glioblastoma cells showed the following. The combined treatment with TCA and riluzole had a greater effect on cell survival than did each drug applied singly. The combined treatment reduced tumour cell proliferation. The drugs increased the effect of conventional treatment with TMZ. Combinations of VPA and TCA or TCA and riluzole reduced the invasion capability of single TCA treatment.

Further evaluation of the use of drug combinations is inevitable; for example, an examination of more cell lines with different genetic backgrounds. These drug combinations should also be tested in animal models. In animal studies, but particularly in human studies, biomarkers for treatment responses should be identified and utilised in therapy decisions. Regardless, the potential for a combination treatment to minimise drug resistance by making cancer cells incapable of adapting to simultaneous toxic effects is supported by the results of this study. Given that these drugs are relatively well tolerated, studies in humans may be possible. 


\section{References}

http://www.abta.org/brain-tumor-information/types-of-tumors/glioblastoma.html; accessed on 29.08.2016

Adamo A, Sesé B, Boue S, Castaño J, Paramonov I, Barrero MJ, Belmonte JCI (2011): LSD1 regulates the balance between self-renewal and differentiation in human embryonic stem cells. Nat Cell Biol 13, 652-659

Amente S, Bertoni A, Morano A, Lania L, Avvedimento EV, Majello B (2010): LSD1-mediated demethylation of histone H3 lysine 4 triggers Myc-induced transcription. Oncogene 29, 3691-3702

Ballas N, Grunseich C, Lu DD, Speh JC, Mandel G (2005): REST and its corepressors mediate plasticity of neuronal gene chromatin throughout neurogenesis. Cell 121, 645-657

Barker CA, Bishop AJ, Chang M, Beal K, Chan TA (2013): Valproic acid use during radiation therapy for glioblastoma associated with improved survival. Int J Radiat Oncol Biol Phys $\underline{86}, 504-509$

Bielecka AM, Obuchowicz E (2016): Antidepressant drugs can modify cytotoxic action of temozolomide. Eur J Cancer Care 26, e12551

Bolden JE, Shi W, Jankowski K, Kan CY, Cluse L, Martin BP, MacKenzie KL, Smyth GK, Johnstone RW (2013): HDAC inhibitors induce tumor-cell-selective pro-apoptotic transcriptional responses. Cell Death Dis $\underline{4}$, e519

Brennan CW, Verhaak RGW, McKenna A, Campos B, Noushmehr H, Salama SR, Zheng S, Chakravarty D, Sanborn JZ, Berman SH, et al. (2013): The somatic genomic landscape of glioblastoma. Cell $\underline{155}, 462-477$

Brocke KS, Staufner C, Luksch H, Geiger KD, Stepulak A, Marzahn J, Schackert G, Temme A, Ikonomidou C (2010): Glutamate receptors in pediatric tumors of the central nervous system. Cancer Biol Ther $\underline{9}$, 455-468

Clarke J, Penas C, Pastori C, Komotar RJ, Bregy A, Shah AH, Wahlestedt C, Ayad NG (2013): Epigenetic pathways and glioblastoma treatment. Epigenetics $\underline{8}, 785-795$

Costello JF, Futscher BW, Kroes RA, Pieper RO (1994): Methylation-related chromatin structure is associated with exclusion of transcription factors from and suppressed expression of the O-6-methylguanine DNA methyltransferase gene in human glioma cell lines. Mol Cell Biol $\underline{14}, 6515-6521$

Dall'Igna OP, Bobermin LD, Souza DO, Quincozes-Santos A (2013): Riluzole increases glutamate uptake by cultured C6 astroglial cells. Int J Dev Neurosci Off J Int Soc Dev Neurosci $\underline{31}$, 482-486

Das CM, Aguilera D, Vasquez H, Prasad P, Zhang M, Wolff JE, Gopalakrishnan V (2007): Valproic acid induces p21 and topoisomerase-II (alpha/beta) expression and synergistically enhances etoposide cytotoxicity in human glioblastoma cell lines. J Neurooncol $\underline{85}$, 159_ 170

de Groot J, Sontheimer H (2011): Glutamate and the biology of gliomas. Glia $\underline{59}, 1181-1189$

Degenhardt K, Mathew R, Beaudoin B, Bray K, Anderson D, Chen G, Mukherjee C, Shi Y, Gélinas C, Fan Y, et al. (2006): Autophagy promotes tumor cell survival and restricts necrosis, inflammation, and tumorigenesis. Cancer Cell $\underline{10}, 51-64$ 
Diaz RJ, Ali S, Qadir MG, De La Fuente MI, Ivan ME, Komotar RJ (2017): The role of bevacizumab in the treatment of glioblastoma. J Neurooncol 133, 455-467

Dong YQ, Liang JS, Zhu SB, Zhang XM, Ji T, Xu JH, Yin GL (2013): Effect of 5-aza-2'deoxycytidine on cell proliferation of non-small cell lung cancer cell line A549 cells and expression of the TFPI-2 gene. Asian Pac J Cancer Prev APJCP 14, 4421-4426

Eckschlager T, Plch J, Stiborova M, Hrabeta J (2017): Histone deacetylase inhibitors as anticancer drugs. Int J Mol Sci 18, 1414

Engel M, Gee YS, Cross D, Maccarone A, Heng B, Hulme A, Smith G, Guillemin GJ, Stringer BW, Hyland CJT, Ooi L (2018): Novel dual-action prodrug triggers apoptosis in glioblastoma cells by releasing a glutathione quencher and lysine-specific histone demethylase $1 \mathrm{~A}$ inhibitor. J Neurochem $\underline{149}$, ,535-550

Fang Y, Liao G, Yu B (2019): LSD1/KDM1A inhibitors in clinical trials: advances and prospects. J Hematol OncolJ Hematol Oncol 12, 129

Fiskus W, Sharma S, Shah B, Portier BP, Devaraj SGT, Liu K, Iyer SP, Bearss D, Bhalla KN (2014): Highly effective combination of LSD1 (KDM1A) antagonist and pan-histone deacetylase inhibitor against human AML cells. Leukemia 28, 2155-2164

Flavahan WA, Wu Q, Hitomi M, Rahim N, Kim Y, Sloan AE, Weil RJ, Nakano I, Sarkaria JN, Stringer BW, et al. (2013): Brain tumor initiating cells adapt to restricted nutrition through preferential glucose uptake. Nat Neurosci $\underline{16}, 1373-1382$

Friday BB, Anderson SK, Buckner J, Yu C, Giannini C, Geoffroy F, Schwerkoske J, Mazurczak M, Gross H, Pajon E, et al. (2012): Phase II trial of vorinostat in combination with bortezomib in recurrent glioblastoma: a north central cancer treatment group study. Neuro-Oncol 14, 215-221

George J, Gondi CS, Dinh DH, Gujrati M, Rao JS (2007): Restoration of tissue factor pathway inhibitor-2 in a human glioblastoma cell line triggers caspase-mediated pathway and apoptosis. Clin Cancer Res Off J Am Assoc Cancer Res 13, 3507-3517

Gessler F, Voss V, Seifert V, Gerlach R, Kögel D (2011): Knockdown of TFPI-2 promotes migration and invasion of glioma cells. Neurosci Lett $\underline{497}, 49-54$

Hanahan D, Weinberg RA (2011): Hallmarks of cancer: the next generation. Cell $\underline{144}$, 646-674

Happold C, Gorlia T, Chinot O, Gilbert MR, Nabors LB, Wick W, Pugh SL, Hegi M, Cloughesy T, Roth P, et al. (2016): Does valproic acid or levetiracetam improve survival in glioblastoma? A pooled analysis of prospective clinical trials in newly diagnosed glioblastoma. J Clin Oncol Off J Am Soc Clin Oncol 34, 731-739

Hart MG, Grant R, Garside R, Rogers G, Somerville M, Stein K (2011): Chemotherapy wafers for high grade glioma. Cochrane Database Syst Rev, $\underline{3}$, CD007294

Herrlinger U, Schäfer N, Steinbach JP, Weyerbrock A, Hau P, Goldbrunner R, Friedrich F, Rohde V, Ringel F, Schlegel U, et al. (2016): Bevacizumab Plus Irinotecan Versus Temozolomide in Newly Diagnosed O6-Methylguanine-DNA Methyltransferase Nonmethylated Glioblastoma: The Randomized GLARIUS Trial. J Clin Oncol Off J Am Soc Clin Oncol $\underline{34}, 1611-1619$ 
Herrlinger U, Tzaridis T, Mack F, Steinbach JP, Schlegel U, Sabel M, Hau P, Kortmann R-D, Krex D, Grauer O, et al. (2019): Lomustine-temozolomide combination therapy versus standard temozolomide therapy in patients with newly diagnosed glioblastoma with methylated MGMT promoter (Ce'TeG/NOA-09): a randomised, open-label, phase 3 trial. Lancet Lond Engl 393, 678-688

Hoffmann I, Roatsch M, Schmitt ML, Carlino L, Pippel M, Sippl W, Jung M (2012): The role of histone demethylases in cancer therapy. Mol Oncol $\underline{6}, 683-703$

Hoja S, Schulze M, Rehli M, Proescholdt M, Herold-Mende C, Hau P, Riemenschneider MJ, Hoja S, Schulze M, Rehli M, et al. (2016): Molecular dissection of the valproic acid effects on glioma cells. Oncotarget $\mathbf{7}$, 62989-63002

Hosein AN, Lim YC, Day B, Stringer B, Rose S, Head R, Cosgrove L, Sminia P, Fay M, Martin JH (2015): The effect of valproic acid in combination with irradiation and temozolomide on primary human glioblastoma cells. J Neurooncol 122, 263-271

Huang J, Sengupta R, Espejo AB, Lee MG, Dorsey JA, Richter M, Opravil S, Shiekhattar R, Bedford MT, Jenuwein T, Berger SL (2007): p53 is regulated by the lysine demethylase LSD1. Nature 449, 105-108

Iser IC, Pereira MB, Lenz G, Wink MR (2017): The epithelial-to-mesenchymal transition-like process in glioblastoma: an updated systematic review and in silico investigation. Med Res Rev 37, 271-313

Jhanwar-Uniyal M, Albert L, McKenna E, Karsy M, Rajdev P, Braun A, Murali R (2011): Deciphering the signaling pathways of cancer stem cells of glioblastoma multiforme: role of Akt/mTOR and MAPK pathways. Adv Enzyme Regul 1ㅗ, 164-170

Jiang H, White EJ, Conrad C, Gomez-Manzano C, Fueyo J (2009): Autophagy pathways in glioblastoma. Methods Enzymol 453, 273-286

Johansen MD, Rochat P, Law I, Scheie D, Poulsen HS, Muhic A (2016): Presentation of two cases with early extracranial metastases from glioblastoma and review of the literature. Case Rep Oncol Med 2016, 1-5

Kanzawa T, Germano IM, Komata T, Ito H, Kondo Y, Kondo S (2004): Role of autophagy in temozolomide-induced cytotoxicity for malignant glioma cells. Cell Death Differ 11, 448457

Kegelman TP, Wu B, Das SK, Talukdar S, Beckta JM, Hu B, Emdad L, Valerie K, Sarkar D, Furnari FB, et al. (2017): Inhibition of radiation-induced glioblastoma invasion by genetic and pharmacological targeting of MDA-9/Syntenin. Proc Natl Acad Sci U S A 114 , 370375

Kerkhof M, Dielemans JCM, van Breemen MS, Zwinkels H, Walchenbach R, Taphoorn MJ, Vecht CJ (2013): Effect of valproic acid on seizure control and on survival in patients with glioblastoma multiforme. Neuro-Oncol 15, 961-967

Khan AJ, Wall B, Ahlawat S, Green C, Schiff D, Mehnert JM, Goydos JS, Chen S, Haffty BG (2011): Riluzole enhances ionizing radiation-induced cytotoxicity in human melanoma cells that ectopically express metabotropic glutamate receptor 1 in vitro and in vivo. Clin Cancer Res Off J Am Assoc Cancer Res 17, 1807-1814

Khan O, La Thangue NB (2012): HDAC inhibitors in cancer biology: emerging mechanisms and clinical applications. Immunol Cell Biol 무, 85-94 
Khasraw M, Ameratunga MS, Grant R, Wheeler H, Pavlakis N (2014): Antiangiogenic therapy for high-grade glioma. Cochrane Database Syst, ㅁ, Rev CD008218

Kloosterhof NK, Bralten LB, Dubbink HJ, French PJ, van den Bent MJ (2011): Isocitrate dehydrogenase-1 mutations: a fundamentally new understanding of diffuse glioma? Lancet Oncol $\underline{12}$, 83-91

Konduri SD, Rao CN, Chandrasekar N, Tasiou A, Mohanam S, Kin Y, Lakka SS, Dinh D, Olivero WC, Gujrati M, et al. (2001): A novel function of tissue factor pathway inhibitor-2 (TFPI2) in human glioma invasion. Oncogene 20, 6938-6945

Kontaki H, Talianidis I (2010): Lysine Methylation Regulates E2F1-Induced Cell Death. Mol Cell $\underline{39}, 152-160$

Kozono D, Li J, Nitta M, Sampetrean O, Gonda D, Kushwaha DS, Merzon D, Ramakrishnan V, Zhu S, Zhu K, et al. (2015): Dynamic epigenetic regulation of glioblastoma tumorigenicity through LSD1 modulation of MYC expression. Proc Natl Acad Sci U S A 112, E40554064

Krauze AV, Myrehaug SD, Chang MG, Holdford DJ, Smith S, Shih J, Tofilon PJ, Fine HA, Camphausen K (2015): A Phase 2 study of concurrent radiation therapy, temozolomide, and the histone deacetylase inhibitor valproic acid for patients with glioblastoma. Int J Radiat Oncol Biol Phys 92, 986-992

Lai A, Kharbanda S, Pope WB, Tran A, Solis OE, Peale F, Forrest WF, Pujara K, Carrillo JA, Pandita A, et al. (2011): Evidence for sequenced molecular evolution of IDH1 mutant glioblastoma from a distinct cell of origin. J Clin Oncol 29, 4482-4490

Lai Y-H, He R-Y, Chou J-L, Chan MW-Y, Li Y-F, Tai C-K (2014): Promoter hypermethylation and silencing of tissue factor pathway inhibitor-2 in oral squamous cell carcinoma. J Transl Med $\underline{12}, 237$

Lee HT, Choi MR, Doh MS, Jung KH, Chai YG (2013): Effects of the monoamine oxidase inhibitors pargyline and tranylcypromine on cellular proliferation in human prostate cancer cells. Oncol Rep $\underline{30}, 1587-1592$

Lee MG, Wynder C, Cooch N, Shiekhattar R (2005): An essential role for CoREST in nucleosomal histone 3 lysine 4 demethylation. Nature $\underline{437}$, 432-435

Lefranc F, Kiss R (2006): Autophagy, the Trojan horse to combat glioblastomas. Neurosurg Focus 20, $1-6$

Louis D, Wiestler OD (Ed.): WHO classification of tumours of the central nervous system. $4^{\text {th }}$ Edition; International Agency for Research on Cancer, Lyon 2016, 1-56

Lucio-Eterovic AKB, Cortez MAA, Valera ET, Motta FJN, Queiroz RGP, Machado HR, Carlotti CG, Neder L, Scrideli CA, Tone LG (2008): Differential expression of 12 histone deacetylase (HDAC) genes in astrocytomas and normal brain tissue: class II and IV are hypoexpressed in glioblastomas. BMC Cancer $\underline{8}, 243$

Lynes J, Sanchez V, Dominah G, Nwankwo A, Nduom E (2018): Current Options and Future Directions in Immune Therapy for Glioblastoma. Front Oncol $\underline{8}, 578$

Maleszewska M, Kaminska B (2013): Is glioblastoma an epigenetic malignancy? Cancers $\underline{5}, 1120$ 1139

Martinez R, Esteller M (2010): The DNA methylome of glioblastoma multiforme. Neurobiol Dis $\underline{39}, 40-46$ 
Methaneethorn J (2018): A systematic review of population pharmacokinetics of valproic acid. Br J Clin Pharmacol $\underline{84}, 816-834$

Metzger E, Wissmann M, Yin N, Müller JM, Schneider R, Peters AHFM, Günther T, Buettner R, Schüle R (2005a): LSD1 demethylates repressive histone marks to promote androgenreceptor-dependent transcription. Nature $\underline{437}, 436-439$

Metzger E, Wissmann M, Yin N, Müller JM, Schneider R, Peters AHFM, Günther T, Buettner R, Schüle R (2005b): LSD1 demethylates repressive histone marks to promote androgenreceptor-dependent transcription. Nature $\underline{437}, 436-439$

Meyer M, Reimand J, Lan X, Head R, Zhu X, Kushida M, Bayani J, Pressey JC, Lionel AC, Clarke ID, et al. (2015): Single cell-derived clonal analysis of human glioblastoma links functional and genomic heterogeneity. Proc Natl Acad Sci U S A $\underline{112}$, 851-856

Micelli C, Rastelli G (2015): Histone deacetylases: structural determinants of inhibitor selectivity. Drug Discov Today 20, $718-735$

Mooney J, Bernstock JD, Ilyas A, Ibrahim A, Yamashita D, Markert JM, Nakano I (2019): Current approaches and challenges in the molecular therapeutic targeting of glioblastoma. World Neurosurg $\underline{129}, 90-100$

Mould DP, McGonagle AE, Wiseman DH, Williams EL, Jordan AM (2015): Reversible inhibitors of LSD1 as therapeutic agents in acute myeloid leukemia: clinical significance and progress to date. Med Res Rev $\underline{35}, 586-618$

Nørøxe DS, Poulsen HS, Lassen U (2017): Hallmarks of glioblastoma: a systematic review. ESMO Open 1 (6), e000144

Perucca E (2013): Optimizing antiepileptic drug treatment in tumoral epilepsy. Epilepsia $\underline{54 \text { Suppl }}$ $\underline{9}, 97-104$

Phillips S, Prat A, Sedic M, Proia T, Wronski A, Mazumdar S, Skibinski A, Shirley SH, Perou CM, Gill G, et al. (2014): Cell-state transitions regulated by SLUG are critical for tissue regeneration and tumor initiation. Stem Cell Rep 2, 633-647

Rhun EL, Preusser M, Roth P, Reardon DA, Bent M van den, Wen P, Reifenberger G, Weller M (2019): Molecular targeted therapy of glioblastoma. Cancer Treat Rev $\underline{80}$

Rogawski MA, Löscher W, Rho JM (2016): Mechanisms of action of antiseizure drugs and the ketogenic diet. Cold Spring Harb Perspect Med $\underline{6}$ (5), a022780

Rosenberg SA, Niglio SA, Salehomoum N, Chan JL-K, Jeong B-S, Wen Y, Li J, Fukui J, Chen S, Shin S-S, Goydos JS (2015): Targeting glutamatergic signaling and the PI3 kinase pathway to halt melanoma progression. Transl Oncol $\underline{8}, 1-9$

Rotili D, Mai A (2011): Targeting Histone Demethylases: A new avenue for the fight against cancer. Genes Cancer 2, 663-679

Schenk T, Chen WC, Göllner S, Howell L, Jin L, Hebestreit K, Klein H-U, Popescu AC, Burnett A, Mills K, et al. (2012a): Inhibition of the LSD1 (KDM1A) demethylase reactivates the alltrans-retinoic acid differentiation pathway in acute myeloid leukemia. Nat Med 18, 605-611

Schenk T, Chen WC, Göllner S, Howell L, Jin L, Hebestreit K, Klein H-U, Popescu AC, Burnett A, Mills K, et al. (2012b): Inhibition of the LSD1 (KDM1A) demethylase reactivates the alltrans-retinoic acid differentiation pathway in acute myeloid leukemia. Nat Med 18, 605-611 
Scholzen T, Gerdes J (2000): The Ki-67 protein: From the known and the unknown. J Cell Physiol $\underline{182}, 311-322$

Seystahl K, Wick W, Weller M (2016): Therapeutic options in recurrent glioblastoma--An update. Crit Rev Oncol Hematol 99, 389-408

Sin W-C, Crespin S, Mesnil M (2012): Opposing roles of connexin43 in glioma progression. Biochim Biophys Acta 1818, 2058-2067

Singh MM, Johnson B, Venkatarayan A, Flores ER, Zhang J, Su X, Barton M, Lang F, Chandra J (2015): Preclinical activity of combined HDAC and KDM1A inhibition in glioblastoma. Neuro-Oncol 17, 1463-1473

Song J, Du Z, Ravasz M, Dong B, Wang Z, Ewing RM (2015): A protein interaction between $\beta$ Catenin and Dnmt1 regulates Wnt signaling and DNA methylation in colorectal cancer Cells. Mol Cancer Res MCR 13, 969-981

Sperling S, Aung T, Martin S, Rohde V, Ninkovic M (2017): Riluzole: a potential therapeutic intervention in human brain tumor stem-like cells. Oncotarget $\underline{8}, 96697-96709$

Speyer CL, Smith JS, Banda M, DeVries JA, Mekani T, Gorski DH (2012): Metabotropic glutamate receptor-1: a potential therapeutic target for the treatment of breast cancer. Breast Cancer Res Treat 132, 565-573

Stengel KR, Hiebert SW (2015): Class I HDACs affect DNA replication, repair, and chromatin structure: implications for cancer therapy. Antioxid Redox Signal 23, 51-65

Stewart BW, Wild CP (Ed.): World Cancer Report 2014, International Agency for Research on Cancer, Lyon 2014, 511-529

Stupp R, Hegi ME, Mason WP, van den Bent MJ, Taphoorn MJB, Janzer RC, Ludwin SK, Allgeier A, Fisher B, Belanger K, et al. (2009): Effects of radiotherapy with concomitant and adjuvant temozolomide versus radiotherapy alone on survival in glioblastoma in a randomised phase III study: 5-year analysis of the EORTC-NCIC trial. Lancet Oncol $\underline{10}$, 459-466

Stupp R, Taillibert S, Kanner AA, Kesari S, Steinberg DM, Toms SA, Taylor LP, Lieberman F, Silvani A, Fink KL, et al. (2015): Maintenance therapy with tumor-treating fields plus temozolomide vs temozolomide alone for glioblastoma: a randomized clinical trial. JAMA $\underline{314}, 2535-2543$

Suraweera A, O’Byrne KJ, Richard DJ (2018): Combination therapy with histone deacetylaseinhibitors (HDACi) for the treatment of cancer: achieving the full therapeutic potential of HDACi. Front Oncol $\underline{8,92}$

Suvà ML, Rheinbay E, Gillespie SM, Patel AP, Wakimoto H, Rabkin SD, Riggi N, Chi AS, Cahill DP, Nahed BV, et al. (2014a): Reconstructing and reprogramming the tumor-propagating potential of glioblastoma stem-like cells. Cell $\underline{157}, 580-594$

Suvà ML, Rheinbay E, Gillespie SM, Patel AP, Wakimoto H, Rabkin SD, Riggi N, Chi AS, Cahill DP, Nahed BV, et al. (2014b): Reconstructing and reprogramming the tumor-propagating potential of glioblastoma stem-like cells. Cell $\underline{157}, 580-594$

Tasiou A, Konduri SD, Yanamandra N, Dinh DH, Olivero WC, Gujrati M, Obeyesekere M, Rao JS (2001): A novel role of tissue factor pathway inhibitor-2 in apoptosis of malignant human gliomas. Int J Oncol $\underline{19}, 591-597$ 
Thotala D, Karvas RM, Engelbach JA, Garbow JR, Hallahan AN, DeWees TA, Laszlo A, Hallahan DE (2015): Valproic acid enhances the efficacy of radiation therapy by protecting normal hippocampal neurons and sensitizing malignant glioblastoma cells. Oncotarget $\underline{6}, 35004$ 35022

Tong JK, Hassig CA, Schnitzler GR, Kingston RE, Schreiber SL (1998): Chromatin deacetylation by an ATP-dependent nucleosome remodelling complex. Nature $\underline{395}, 917-921$

Vaitkienė P, Skiriute D, Skauminas K, Tamašauskas A (2012): Associations between TFPI-2 methylation and poor prognosis in glioblastomas. Med Kaunas Lith $\underline{48}, 345-349$

Verhaak RGW, Hoadley KA, Purdom E, Wang V, Qi Y, Wilkerson MD, Miller CR, Ding L, Golub T, Mesirov JP, et al. (2010): Integrated genomic analysis identifies clinically relevant subtypes of glioblastoma characterized by abnormalities in PDGFRA, IDH1, EGFR, and NF1. Cancer Cell 17, 98-110

Wang Y, Zhang H, Chen Y, Sun Y, Yang F, Yu W, Liang J, Sun L, Yang X, Shi L, et al. (2009): LSD1 is a subunit of the NuRD complex and targets the metastasis programs in breast cancer. Cell $\underline{138}$, 660-672

Weller M, Gorlia T, Cairncross JG, van den Bent MJ, Mason W, Belanger K, Brandes AA, Bogdahn U, Macdonald DR, Forsyth P, et al. (2011): Prolonged survival with valproic acid use in the EORTC/NCIC temozolomide trial for glioblastoma. Neurology $77,1156-1164$

Wen Y, Li J, Koo J, Shin S-S, Lin Y, Jeong B-S, Mehnert JM, Chen S, Cohen-Sola KA, Goydos JS (2014): Activation of the glutamate receptor GRM1 enhances angiogenic signaling to drive melanoma progression. Cancer Res $\underline{74}$, 2499-2509

Willard SS, Koochekpour S (2013): Glutamate signaling in benign and malignant disorders: current status, future perspectives, and therapeutic implications. Int J Biol Sci $\underline{9}, 728-742$

Wojtukiewicz MZ, Sierko E, Zimnoch L, Kozlowski L, Kisiel W (2003): Immunohistochemical localization of tissue factor pathway inhibitor-2 in human tumor tissue. Thromb Haemost $\underline{90}, 140-146$

Yang R, Wu Y, Wang M, Sun Z, Zou J, Zhang Y, Cui H (2015): HDAC9 promotes glioblastoma growth via TAZ-mediated EGFR pathway activation. Oncotarget $\underline{6}, 7644-7656$

Ye ZC, Sontheimer H (1999): Glioma cells release excitotoxic concentrations of glutamate. Cancer Res $\underline{59}, 4383-4391$

Yelskaya Z, Carrillo V, Dubisz E, Gulzar H, Morgan D, Mahajan SS (2013): Synergistic inhibition of survival, proliferation, and migration of U87 cells with a combination of LY341495 and Iressa. PloS One $\underline{8}, 1-10$

Yi L, Cui Y, Xu Q, Jiang Y (2016): Stabilization of LSD1 by deubiquitinating enzyme USP7 promotes glioblastoma cell tumorigenesis and metastasis through suppression of the p53 signaling pathway. Oncol Rep $\underline{36}$, 2935-2945

You A, Tong JK, Grozinger CM, Schreiber SL (2001): CoREST is an integral component of the CoREST- human histone deacetylase complex. Proc Natl Acad Sci U S A $\underline{98}, 1454-1458$

Yu C, Friday BB, Yang L, Atadja P, Wigle D, Sarkaria J, Adjei AA (2008): Mitochondrial Bax translocation partially mediates synergistic cytotoxicity between histone deacetylase inhibitors and proteasome inhibitors in glioma cells. Neuro-Oncol 10, 309-319

Yu LJ, Wall BA, Wangari-Talbot J, Chen S (2017): Metabotropic glutamate receptors in cancer. Neuropharmacology $\underline{115}, 193-202$ 
Yung WK, Albright RE, Olson J, Fredericks R, Fink K, Prados MD, Brada M, Spence A, Hohl RJ, Shapiro W, et al. (2000): A phase II study of temozolomide vs. procarbazine in patients with glioblastoma multiforme at first relapse. Br J Cancer $\underline{83}, 588-593$

Zhang C, Yuan X, Li H, Zhao Z, Liao Y, Wang X, Su J, Sang S, Liu Q (2015): Anti-cancer effect of metabotropic glutamate receptor 1 inhibition in human glioma U87 cells: involvement of PI3K/Akt/mTOR pathway. Cell Physiol Biochem Int J Exp Cell Physiol Biochem Pharmacol $\underline{35}, 419-432$

Zhang C, Liu S, Yuan X, Hu Z, Li H, Wu M, Yuan J, Zhao Z, Su J, Wang X, et al. (2016): Valproic acid promotes human glioma U87 cells apoptosis and inhibits Glycogen Synthase Kinase$3 \beta$ Through ERK/Akt Signaling. Cell Physiol Biochem Int J Exp Cell Physiol Biochem Pharmacol $\underline{39}$, 2173-2185

Zhang Q, Zhang Y, Wang SZ, Wang N, Jiang WG, Ji YH, Zhang SL (2012): Reduced expression of tissue factor pathway inhibitor-2 contributes to apoptosis and angiogenesis in cervical cancer. J Exp Clin Cancer Res CR $\underline{31}, 1$

Zhang Q, Wang S, Chen J, Yu Z (2019): Histone Deacetylases (HDACs) Guided novel therapies for T-cell lymphomas. Int J Med Sci $\underline{16}, 424-442$

Zhang Z, Wang Y, Chen J, Tan Q, Xie C, Li C, Zhan W, Wang M (2016): Silencing of histone deacetylase 2 suppresses malignancy for proliferation, migration, and invasion of glioblastoma cells and enhances temozolomide sensitivity. Cancer Chemother Pharmacol $\underline{78}, 1289-1296$

Zheng Y-C, Ma J, Wang Z, Li J, Jiang B, Zhou W, Shi X, Wang X, Zhao W, Liu H-M (2015): A Systematic review of histone lysine-specific demethylase 1 and its inhibitors. Med Res Rev $\underline{35}, 1032-1071$ 


\section{Acknowledgements}

I express my deepest gratitude to my supervisor Prof. Dr. med. Rohde for enormous support and valuable clinical advice. I also appreciate the competent advice, kind help and motivation from Dr. Ninkovic and her colleague Swetlana Sperling. Without their persistent help, the goal of this project would not have been realised. I pay my special regards to thank Julia Bode (Schaller Research Group at the University of Heidelberg and the DKFZ, Deutsches Krebsforschungszentrum (V077), Heidelberg, Germany). I thank all the people from our partner institutions of the University Medical Centre of Göttingen, whose assistance was a milestone in the completion of this project. I pay my special regards to Prof. Dr. med. Brockmöller for his kind advice and motivation during the final, and the most complicated, phase of this thesis. I also acknowledge the support of my family and friends for their motivation and patience during the whole project. I further thank all the people who supported me during the experimental work and writing of this thesis. 